\title{
Aerosol modelling in Europe with a focus on Switzerland during summer and winter episodes
}

\author{
S. Aksoyoglu, J. Keller, I. Barmpadimos, D. Oderbolz, V. A. Lanz, A. S. H. Prévôt, and U. Baltensperger \\ Paul Scherrer Institut, Laboratory of Atmospheric Chemistry, 5232 Villigen PSI, Switzerland \\ Received: 10 March 2011 - Published in Atmos. Chem. Phys. Discuss.: 6 April 2011 \\ Revised: 18 July 2011 - Accepted: 21 July 2011 - Published: 26 July 2011
}

\begin{abstract}
This paper describes aerosol modelling in Europe with a focus on Switzerland during summer and winter periods. We modelled $\mathrm{PM}_{2.5}$ (particles smaller than $2.5 \mu \mathrm{m}$ in aerodynamic diameter) for one summer and two winter periods in years 2006 and 2007 using the CAMx air quality model. The meteorological fields were obtained from MM5 simulations. The modelled wind speeds during some lowwind periods, however, had to be calibrated with measurements to use realistic input for the air quality model. The detailed AMS (aerosol mass spectrometer) measurements at specific locations were used to evaluate the model results. In addition to the base case simulations, we carried out sensitivity tests with modified aerosol precursor emissions, air temperature and deposition. Aerosol concentrations in winter 2006 were twice as high as those in winter 2007, however, the chemical compositions were similar. CAMx could reproduce the relative composition of aerosols very well both in the winter and summer periods. Absolute concentrations of aerosol species were underestimated by about $20 \%$. Both measurements and model results suggest that organic aerosol $(30-38 \%)$ and particulate nitrate $(30-36 \%)$ are the main aerosol components in winter. In summer, organic aerosol dominates the aerosol composition (55-57\%) and is mainly of secondary origin. The contribution of biogenic volatile organic compound (BVOC) emissions to the formation of secondary organic aerosol (SOA) was predicted to be very large (>95\%) in Switzerland. The main contributors to the modelled SOA concentrations were oxidation products of monoterpenes and sesquiterpenes as well as oligomerization of oxidized compounds. The fraction of primary organic aerosol (POA) derived from measurements was lower than the model predictions indicating the importance of volatility
\end{abstract}

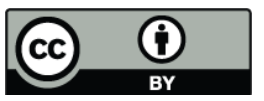

Correspondence to: S. Aksoyoglu (sebnem.aksoyoglu@psi.ch) of POA, which has not yet been taken into account in CAMx. Sensitivity tests with reduced $\mathrm{NO}_{\mathrm{x}}$ and $\mathrm{NH}_{3}$ emissions suggest that aerosol formation is more sensitive to ammonia emissions in winter in a large part of Europe. In Switzerland however, aerosol formation is predicted to be $\mathrm{NO}_{\mathrm{x}}$-sensitive. In summer, effects of $\mathrm{NO}_{\mathrm{x}}$ and $\mathrm{NH}_{3}$ emission reductions on aerosol concentrations are predicted to be lower mostly due to lower ammonium nitrate concentrations. In general, the sensitivity to $\mathrm{NH}_{3}$ emissions is weaker in summer due to higher $\mathrm{NH}_{3}$ emissions.

\section{Introduction}

Atmospheric aerosols are known to have adverse health effects. They also play an important role in climate change by modifying the radiative balance of the atmosphere (IPCC, 2007). $\mathrm{PM}_{10}$ concentrations in Switzerland frequently exceed the national ambient air quality standards (20 and $50 \mu \mathrm{g} \mathrm{m}^{-3}$, annual and daily averages, respectively). Several long-term PM measurements as well as data obtained from field campaigns show that the organic portion is highly abundant (Lanz et al., 2010; Hueglin et al., 2006). Organic aerosol (OA) is composed of both directly emitted primary OA (POA) and secondarily formed SOA. OA has significant effects on climate and human health, but its sources and evolution in the atmosphere are not yet fully understood. New studies indicate that oxygenated organic aerosol (OOA) is formed from $\mathrm{OA}$ and its precursor gases, which becomes increasingly oxidized, less volatile, and more hygroscopic (Jimenez et al., 2009). Analysis of the submicron aerosol in Switzerland revealed that only a small fraction of OA originates from freshly emitted fossil fuel combustion, and that a high fraction is composed of OOA (Lanz et al., 2010). This conclusion was based on analyses of the organic aerosol

Published by Copernicus Publications on behalf of the European Geosciences Union. 

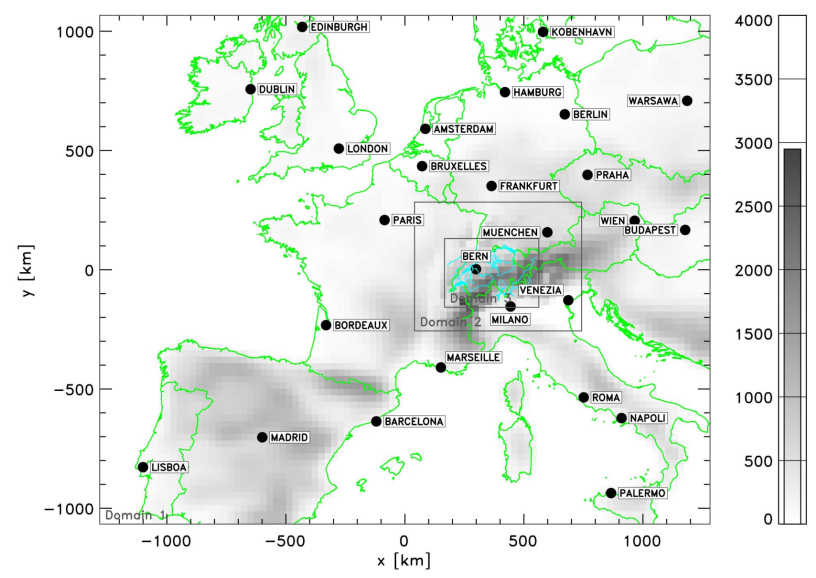

Fig. 1. Terrain heights ( $\mathrm{m}$ asl.) of the model domains with horizontal resolutions of $27 \mathrm{~km} \times 27 \mathrm{~km}$ (domain 1), $9 \mathrm{~km} \times 9 \mathrm{~km}$ (domain 2), $3 \mathrm{~km} \times 3 \mathrm{~km}$ (domain 3 ).

mass spectra by positive matrix factorization (Lanz et al., 2007) and by multi-linear engine 2 (Lanz et al., 2008). Modelling organic aerosol is among the most demanding aspects of air quality simulations because the formation processes and evolution are poorly understood. In spite of the recent improvements in air quality models, organic aerosols can be underestimated by a large amount (Hodzic et al., 2009). The recently-developed volatility basis-set approach (Donahue et al., 2006) improved the agreement between organic aerosol model results and aerosol mass spectrometer (AMS) measurements (Robinson et al., 2007; Dzepina et al., 2009; Tsimpidi et al., 2010; Hodzic et al., 2010). The discrepancy between models and measurements has also been reduced by taking into account other processes such as the formation of SOA via aqueous chemistry (Carlton et al., 2008), oligomerization (Morris et al., 2006), the addition of new precursors (Zhang et al., 2007; Carlton et al., 2010), the treatment of SOA hygroscopicity (Pun, 2008), the treatment of SOA formation under low- $\mathrm{NO}_{\mathrm{x}}$ conditions (Carlton et al., 2010).

Several PM measurements during January 2006 in Switzerland found exceptionally high concentrations (Lanz et al., 2008). Additional measurements were made at Payerne in June 2006 and in January 2007 within the frame of EMEP (European Monitoring and Evaluation Programme). These detailed aerosol measurements provide a good data base to test models under different meteorological conditions over the complex terrain of Switzerland. In this study, we used the MM5/CAMx model system to simulate the air quality in Europe in one summer (June 2006) and two winter periods (January 2006, January 2007), focussing on the particulate matter in Switzerland.
Table 1. SOA precursor reactions included in CAMx (Environ, 2008).

\begin{tabular}{|c|c|c|c|}
\hline Precursor & Reaction & CG Products ${ }^{1}$ & $\begin{array}{l}\mathrm{K}_{298}^{2} \\
\left(\mathrm{ppm}^{-1} \mathrm{~min}^{-1}\right)\end{array}$ \\
\hline \multicolumn{4}{|l|}{ Anthropogenic } \\
\hline Toluenes & $\mathrm{TOLA}+\mathrm{OH}$ & 0.044 CG1+0.085 CG2 & $8.75 \mathrm{E}+03$ \\
\hline Xylenes & $\mathrm{XYLA}+\mathrm{OH}$ & 0.027 CG1+0.118 CG2 & $3.71 \mathrm{E}+04$ \\
\hline \multicolumn{4}{|l|}{ Biogenic } \\
\hline \multirow[t]{4}{*}{ Isoprene } & $\mathrm{ISP}+\mathrm{O}$ & none & $5.32 \mathrm{E}+04$ \\
\hline & $\mathrm{ISP}+\mathrm{OH}$ & 0.015 CG3+0.12 CG4 & $1.47 \mathrm{E}+05$ \\
\hline & $\mathrm{ISP}+\mathrm{O}_{3}$ & none & $1.90 \mathrm{E}-02$ \\
\hline & $\mathrm{ISP}+\mathrm{NO}_{3}$ & none & $9.96 \mathrm{E}+02$ \\
\hline \multirow[t]{4}{*}{ Terpenes } & $\mathrm{TRP}+\mathrm{O}$ & 0.065 CG5+0.29 CG6 & $4.12 \mathrm{E}+04$ \\
\hline & $\mathrm{TRP}+\mathrm{OH}$ & 0.065 CG5+0.29 CG6 & $7.76 \mathrm{E}+04$ \\
\hline & $\mathrm{TRP}+\mathrm{O}_{3}$ & 0.065 CG5+0.29 CG6 & $1.33 \mathrm{E}-01$ \\
\hline & $\mathrm{TRP}+\mathrm{NO}_{3}$ & 0.065 CG5+0.29 CG6 & $9.18 \mathrm{E}+03$ \\
\hline \multirow[t]{3}{*}{ Sesquiterpenes } & $\mathrm{SQT}+\mathrm{OH}$ & 0.85 CG7 & $2.91 \mathrm{E}+05$ \\
\hline & $\mathrm{SQT}+\mathrm{O}_{3}$ & 0.85 CG7 & $1.71 \mathrm{E}+01$ \\
\hline & $\mathrm{SQT}+\mathrm{NO}_{3}$ & 0.85 CG7 & $2.81 \mathrm{E}+04$ \\
\hline
\end{tabular}

${ }^{1}$ Yield values are in $\mathrm{ppm} \mathrm{ppm}^{-1} .{ }^{2}$ Rate constants are shown for $298 \mathrm{~K}$ and 1 atmosphere in $\mathrm{ppm}^{-1} \mathrm{~min}^{-1}$.

Table 2. Properties of CG/SOA pairs in CAMx (Environ, 2008).

\begin{tabular}{lrrr}
\hline Species & $\begin{array}{r}\text { Molecular } \\
\text { Weight } \\
\left(\mathrm{g} \mathrm{mole}^{-1}\right)\end{array}$ & $\begin{array}{r}\text { Saturation } \\
\text { Concentration } \\
\left(\mu \mathrm{g} \mathrm{m}^{-3} \text { at 298 K }\right)\end{array}$ & $\begin{array}{r}\text { Heat of } \\
\text { vaporization } \\
\left(\mathrm{kJ} \mathrm{mole}^{-1}\right)\end{array}$ \\
\hline CG1/SOA1 & 150 & 7.82 & 66.8 \\
CG2/SOA2 & 150 & 227 & 66.8 \\
CG3/SOA3 & 130 & 0.726 & 42 \\
CG4/SOA4 & 130 & 136 & 42 \\
CG5/SOA5 & 180 & 3.92 & 75.5 \\
CG6/SOA6 & 180 & 55.8 & 75.5 \\
CG7/SOA7 & 210 & 0 & - \\
SOPA & 220 & - & - \\
SOPB & 220 & - & - \\
\hline
\end{tabular}

\section{Modelling method}

\subsection{Model setup}

We used the CAMx (Comprehensive Air Quality Model with extensions) model, version 4.51 (Environ, 2008) to simulate air quality in January 2006, June 2006, and January 2007. The meso-scale model MM5, version 3.7.4 (PSU/NCAR, 2004) was used to generate the meteorological fields for CAMx. Three nested model domains were used in a Lambert Conic Conformal projection using 1-way nesting to cover a large part of Europe, central Europe and Switzerland with horizontal resolutions of $27 \mathrm{~km} \times 27 \mathrm{~km}, 9 \mathrm{~km} \times 9 \mathrm{~km}$, and $3 \mathrm{~km} \times 3 \mathrm{~km}$, respectively (Fig. 1). The MM5 simulations with 31 terrain-following $\sigma$-levels up to $100 \mathrm{hPa}$, were initialized by data from COSMO7 analysis (COSMO, 2002). 

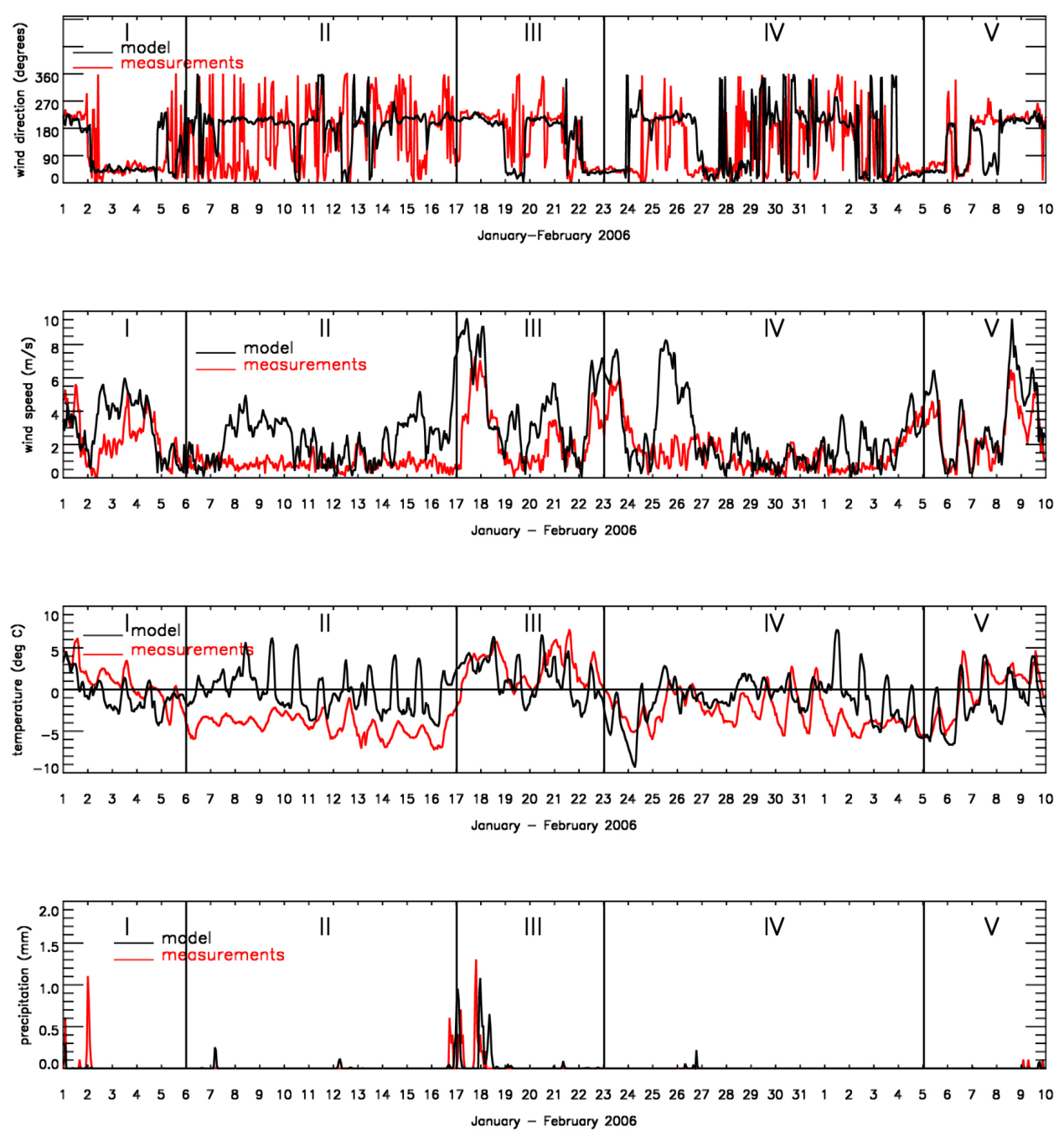

Fig. 2. Comparison of measured and modelled wind direction (deg), wind speed $\left(\mathrm{m} \mathrm{s}^{-1}\right)$, air temperature $\left({ }^{\circ} \mathrm{C}\right)$ and precipitation $(\mathrm{mm})$ at Payerne (NABEL station) in January-February 2006.

Four-dimensional data analysis (FDDA) using COSMO7 data was applied only for domains 1 and 2. The planetary boundary layer (PBL) height was calculated using the Eta PBL option, with the Mellor-Yamada scheme (Janjić, 1994). The CAMx simulations used a subset of 14 of the MM5 $\sigma$-layers, of which the lowest had a thickness of about $40 \mathrm{~m}$ at a surface pressure of $950 \mathrm{hPa}$. The model top was set at $\sigma=0.55$ which corresponds to a geometric layer top of about $7000 \mathrm{~m}$ above sea level. The initial and boundary concentrations for the first domain were obtained from the global model MOZART (Horowitz et al., 2003). The photolysis rates were calculated using the TUV photolysis preprocessor (Madronich, 2002). The required ozone column densities were extracted from TOMS data (NASA/GSFC, 2005). Dry deposition of gases was based on the resistance model of Wesely (1989). Surface deposition of particles occurs via diffusion, impaction and/or gravitational settling.
Separate scavenging models for gases and aerosols were implemented in CAMx to calculate the wet deposition (Environ, 2008). The CB05 gas-phase mechanism was used (Yarwood et al., 2005). We performed the simulations for the same periods as the detailed field campaigns where measurements were conducted with an aerosol mass spectrometer (AMS) at Zurich in January 2006 (Lanz et al., 2008) and at Payerne in June 2006 and January 2007 (EMEP campaigns) (Lanz et al., 2010).

Simulated aerosol species with particle sizes smaller than $2.5 \mu \mathrm{m}$ included sulphate, nitrate, ammonium, POA, SOA and elemental carbon (EC). The condensable organic gases (CG) are formed from the oxidation of the aromatic precursors TOL (toluene) and XYL (xylene), as well as of the biogenic precursors isoprene, monoterpenes and sesquiterpenes (see Table 1 for the SOA precursor reactions). Partitioning of condensable organic gases to secondary organic aerosols was 

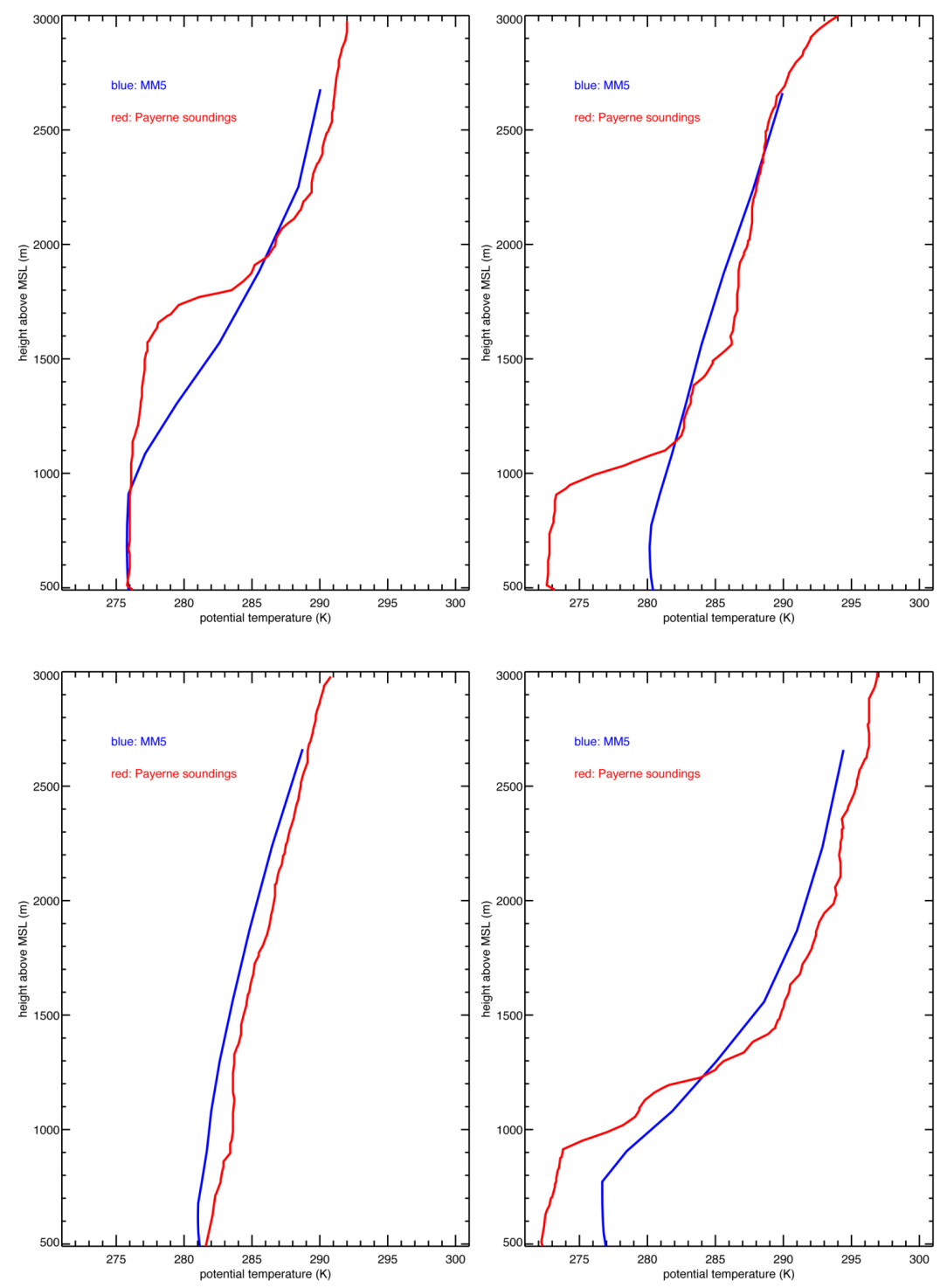

Fig. 3. Comparison of vertical profiles of potential temperature $(\mathrm{K})$ at 12:00 local time from soundings at Payerne (red) and from MM5 meteorological model (blue). Top left: 4 January (period I), top right: 9 January (period II), bottom left: 18 January (period III), bottom right: 3 February (period IV).

calculated using a semi-volatile equilibrium scheme called SOAP (Strader, 1999). Properties of CG/SOA pairs used in CAMx are given in Table 2. Oligomerization is taken into account in a rather simple way in CAMx. It was assumed that the SOA oligomerized to a non-volatile form with a lifetime of about 1 day (Kalberer et al., 2004). Oligomerization slowly forms organic aerosol oligomers called SOPA (anthropogenic) and SOPB (biogenic), and it was shown to increase SOA yields (Morris et al., 2006). Pun and Seigneur (2007) reported that oligomerization may be $\mathrm{pH}-$ dependent and therefore further work is needed to correctly simulate this process. Aqueous sulphate and nitrate formation in cloud water were calculated using the RADM aqueous chemistry algorithm (Chang et al., 1987). Cloud production of SOA is not taken into account in CAMx. Partitioning of inorganic aerosol constituents between the gas and particulate phases was modelled with ISORROPIA (Nenes et al., 1998). The model results for each episode were evaluated mainly at locations where detailed aerosol measurements were available: Zurich (January 2006) and Payerne (June 2006 and January 2007). In addition to the base case simulations, sensitivity tests were performed with modified parameters such as precursor emissions (two simulations with a $50 \%$ emission reduction of either $\mathrm{NH}_{3}$ or $\mathrm{NO}_{\mathrm{x}}$ ), air temperature $\left( \pm 5^{\circ} \mathrm{C}\right)$ and deposition (on/off). 


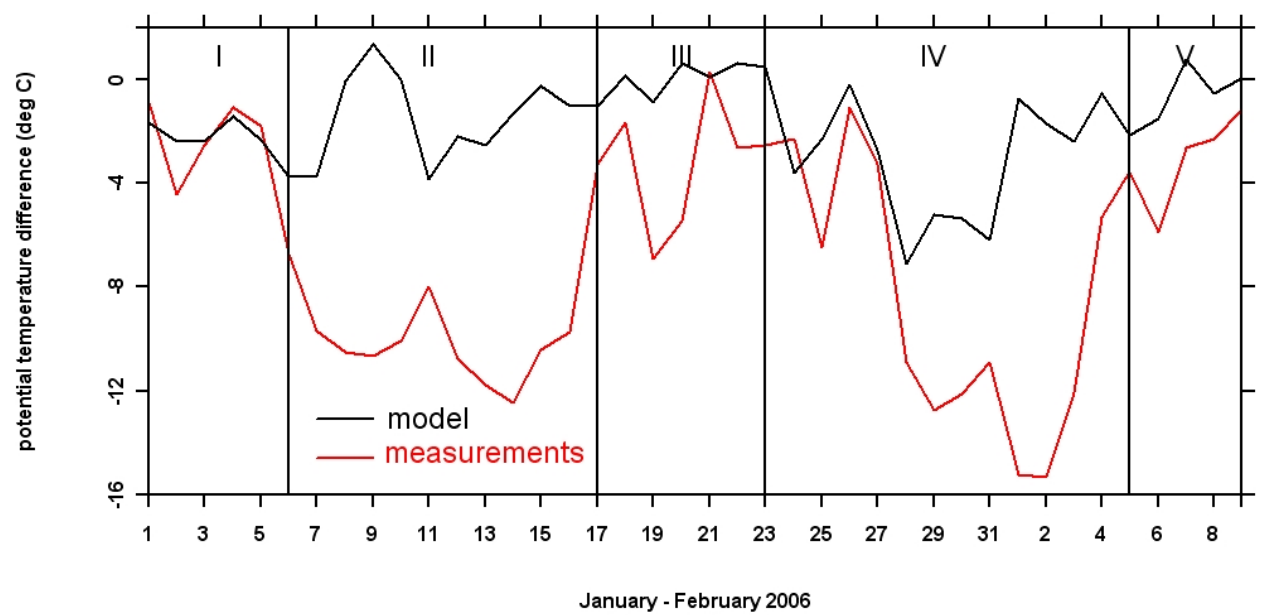

Fig. 4. Difference of potential temperature $(\Delta \theta)$ between Payerne (NABEL station, $489 \mathrm{~m}$ a.s.1.) and Chaumont (MeteoSwiss station, 1137 m a.s.l.) during January-February 2006 (data at 12:00 UTC); measurements in red, MM5 model results in black.

\subsection{Emissions}

Gridded emissions from various sources refer to a specific year. To harmonize data from different sources and reference years, emissions were converted to a common reference year, 2005. The annual emissions and time functions for $\mathrm{Eu}-$ rope were provided by the Freie Universität Berlin (FUB) (Stern, 2003; Builtjes et al., 2002). The spatial resolution was $0.125 \mathrm{deg} \times 0.25 \mathrm{deg}$. The region of Lombardy in northern Italy was treated differently using hourly emissions (CITYDELTA, 2002). Emissions in Switzerland were also calculated separately. Annual road traffic emission data with a spatial resolution of $250 \mathrm{~m}$ as well as the spatial distributions of total annual NMVOC emissions from industry and households with a resolution of $200 \mathrm{~m}$ were provided by INFRAS (Heldstab and Wuethrich, 2006; Keller and de Haan, 2004). The total NMVOC emission was split into the CB05 species following the rules of Passant (2002). Annual $\mathrm{NO}_{\mathrm{x}}, \mathrm{PM}_{2.5}$ and $\mathrm{PM}_{10}$ emissions from residential activities, heating, industry, off-road traffic, rail transport and agriculture/forestry on a $200 \mathrm{~m}$ resolution as well as ammonia emissions from manure, waste treatment and road traffic on a $1 \mathrm{~km}$ resolution were taken from Meteotest. Industrial and residential emissions include substantial percentages of biomass burning. In Switzerland, about $75 \%$ of the residential $\mathrm{PM}_{10}$ emissions, $10 \%$ of the industrial and $23 \%$ of the agricultural and forestal emissions are released by biomass combustion. Currently, the annual PM emissions from road traffic are about 3-4 times higher than those from domestic wood burning in our inventory. Primary particulate emissions were split as $40 \%$ elemental carbon (EC) and $60 \%$ OA (Szidat et al., 2006).

Biogenic emissions for the CAMx domains were calculated using European and Swiss land use inventories and MM5 meteorological data. For each European country the deciduous and coniferous forest fractions were split into separate tree species according to Simpson et al. (1999). Inside Switzerland, the global data were replaced by data of the "Arealstatistik" (100 m resolution) issued by the Federal Office of Statistics (BFS, 1999) and by forest data (1 km resolution) taken from the "Landesforstinventar" (Mahrer and Vollenweider, 1983). About $24 \%$ of the Swiss area is covered by forests of which $71 \%$ are coniferous. Norway Spruce (picea abies) and fir (abies alba) are the most abundant species (49\% and $15 \%$ of the trees, respectively). Monoterpenes are the most important biogenic VOC species in Switzerland, emitted mainly by Norway Spruce and fir trees. Isoprene in Switzerland, on the other hand, is emitted mostly by oak trees, which constitute only $2 \%$ of the Swiss forests. The method for the estimation of biogenic emissions is given in Andreani-Aksoyoglu and Keller (1995), which was updated using recent literature data. The emission rates of sesquiterpenes were assumed to be $10 \%$ (in moles) of those of monoterpenes, based on data relevant for Swiss forests in Steinbrecher et al. (2009).

\subsection{Meteorology}

\subsubsection{Winter 2006}

Before evaluating the results of chemistry-transport model CAMx, we analysed the meteorological variables because they are essential for the dispersion and vertical mixing of pollutants. We modelled the meteorological parameters between 1 January and 10 February 2006. We classified the meteorological conditions into 5 periods using the time series of measurements at various meteorological stations in Switzerland (see Fig. 2 for Payerne). During the first period (1-5 January), the measured air temperatures were mostly above zero, wind speed was moderate and there was no 


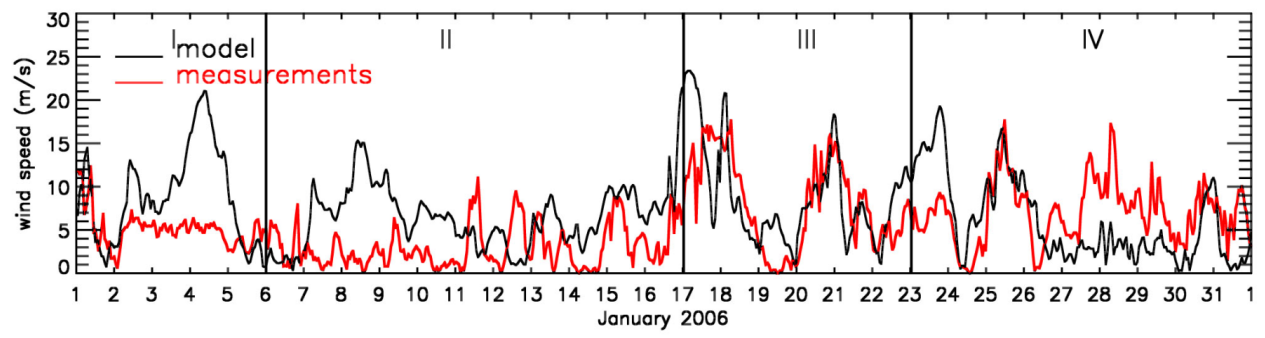

Fig. 5. Comparison of modelled wind speed $\left(\mathrm{m} \mathrm{s}^{-1}\right)$ at the 6th model level (mid-point at approximately $992 \mathrm{~m}$ a.s.1.) with measurements at Uetliberg (ENET station, $1043 \mathrm{~m}$ a.s.1.) in January 2006.
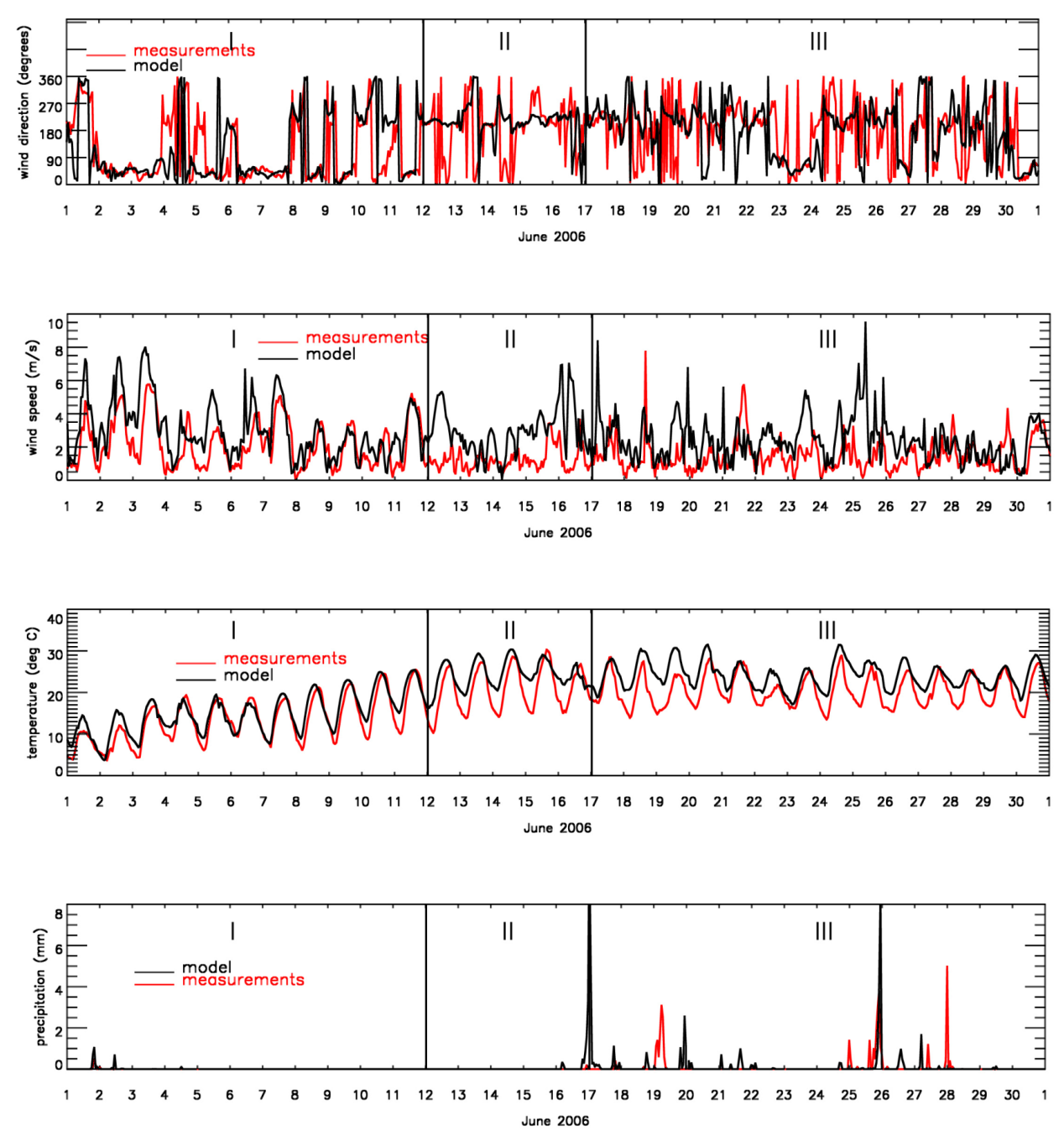

Fig. 6. Comparison of measured and modelled wind direction (deg), wind speed $\left(\mathrm{m} \mathrm{s}^{-1}\right)$, air temperature $\left({ }^{\circ} \mathrm{C}\right)$ and precipitation $(\mathrm{mm})$ at Payerne (NABEL station) in June 2006. 

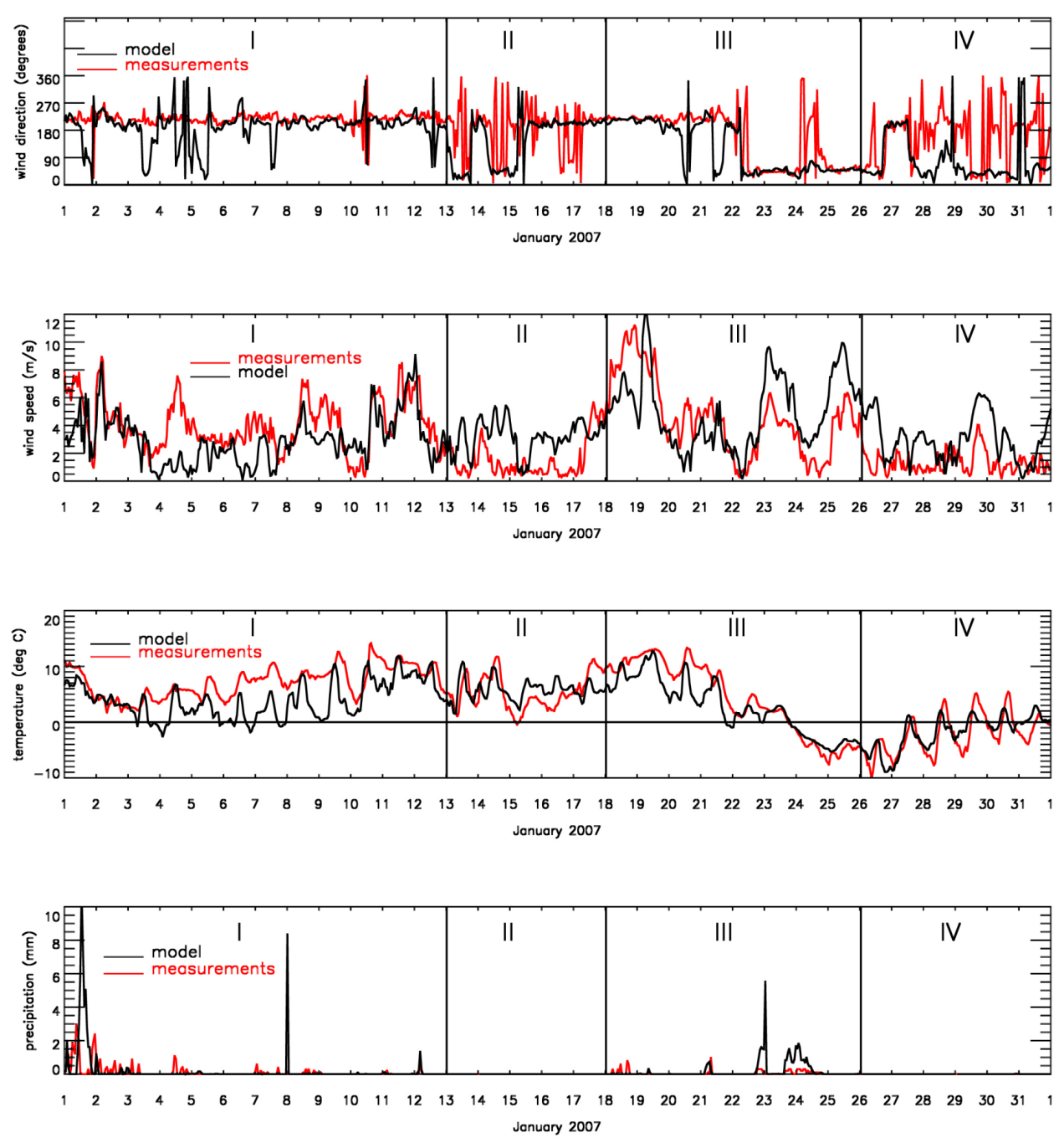

Fig. 7. Comparison of measured and modelled wind direction $(\mathrm{deg})$, wind speed $\left(\mathrm{m} \mathrm{s}^{-1}\right)$, air temperature $\left({ }^{\circ} \mathrm{C}\right)$ and precipitation $(\mathrm{mm})$ at Payerne (NABEL station) in January 2007.

precipitation except at the beginning. The second period (616 January) was characterized by low-wind speed and an extended fog layer over the Swiss Plateau (region between the Jura and the Alps), as well as lower temperatures. Then a warm front arrived, causing precipitation, higher wind speed and a rapid temperature increase in the third period (17-22 January). Mixed conditions prevailed during the fourth period (23 January-4 February). In the last period (5-10 February), temperatures and wind speed increased. The model reproduced the wind direction and precipitation quite well most of the time. However, there was some difference (with a maximum of $\pm 5^{\circ} \mathrm{C}$ ) between the measured and modelled temperature in the lowest model layer. The effect of such a difference in temperature on pollutant concentrations was investigated with sensitivity tests and is discussed in Sect. 3.3. The meteorological model could reproduce wind fields reasonably well for the days with strong winds, but overesti- mated the low-wind speeds especially in periods II and IV. A common element between periods II and IV was the prevalence of temperature inversions. The comparison of vertical profiles of potential temperature predicted by MM5 with those from soundings at Payerne clearly shows that the temperature inversions during the periods II and IV could not be reproduced (see Fig. 3 for some examples). Temperature inversions were further investigated by examining the differences between the potential temperatures $(\Delta \theta)$ at Payerne and Chaumont. These stations are relatively close to each other (about $25 \mathrm{~km}$ ) and the elevation at Chaumont is about $650 \mathrm{~m}$ higher than at Payerne. Thus $\Delta \theta$ can be used as a way to detect the presence of a temperature inversion. As shown in Fig. 4, there was a sharp decrease in the measured $\Delta \theta$ at the beginning of period II. At the end of that period $\Delta \theta$ increased abruptly. We note that a similar sharp decrease in $\Delta \theta$ occurred also in period IV. This implies the 

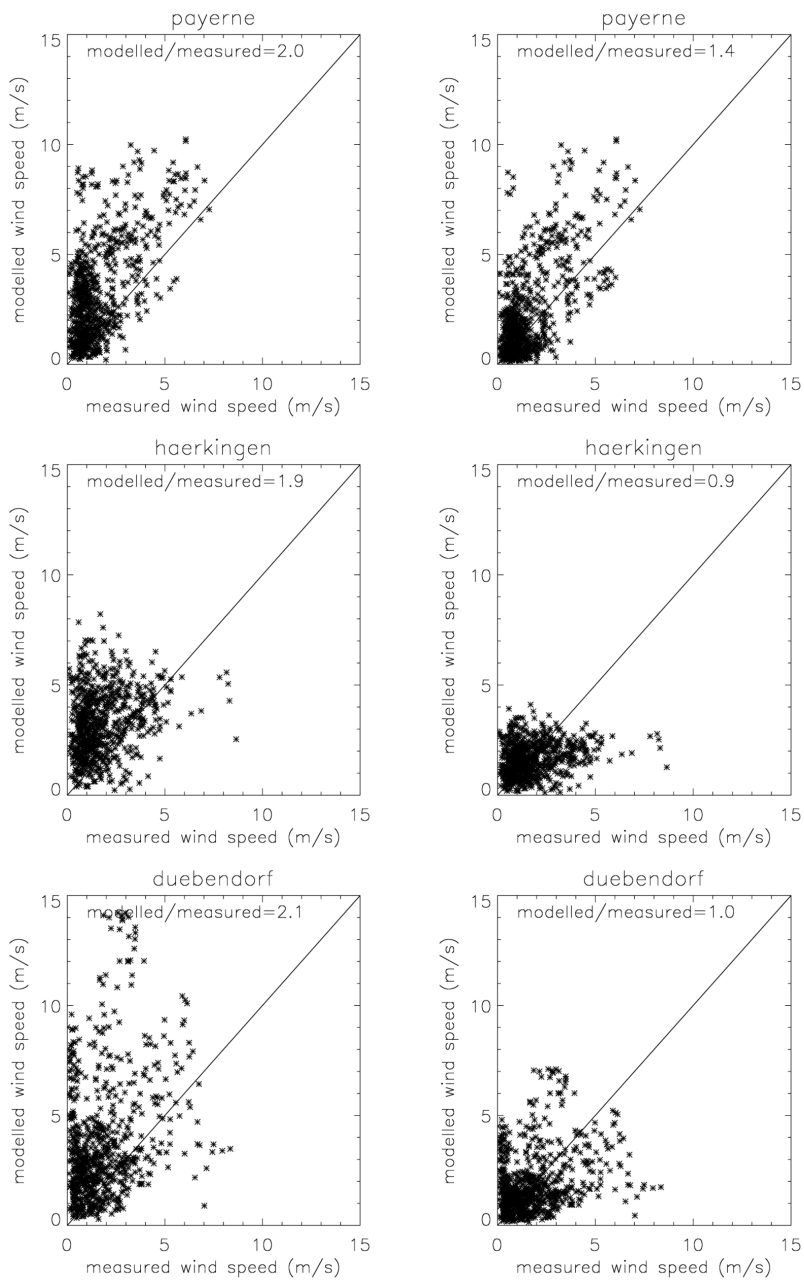

Fig. 8. Comparison of modelled and measured wind speed at Payerne (rural) in January 2006 (top), at Haerkingen (motorway) in June 2006 (middle) and at Duebendorf (suburban) in January 2007 (bottom), before (left) and after the adjustment (right). The term modelled/measured in each plot represents the slope of the correlation.

development of a temperature inversion. The contrast between low-wind (II and IV) and high-wind periods (I, III and V) can be clearly seen in Fig. 4. During the times when the meteorological model results do not follow the observations, the vertical structure of the atmosphere is not simulated accurately, which is consistent with the findings from the comparison of simulated and observed profiles of potential temperature (Fig. 3). We also compared the modelled wind speeds at higher altitudes with measurements on a television tower at Uetliberg (1043 ma.s.l.). Figure 5 shows that wind speeds at higher vertical levels were also overestimated as in the case of surface layer.

\subsubsection{Summer 2006}

The summer period in June 2006 was divided into 3 parts (Fig. 6). Measurements and model predictions for meteorological parameters matched reasonably well in the first period (1-11 June), which was mostly dry with increasing temperatures and moderate to strong winds. In the second period (12-16 June), low wind speeds and night temperatures were overestimated by the model. This implies that the model underestimates the radiative cooling during the night. Strong radiative cooling at night leads to strong stratification which in turn is associated with high pollution levels. Inadequate representation of this phenomenon in the model probably contributes to an underestimation of pollutant levels after 12 June. During the first period the night-time surface inversion was not very strong. In the second period however, there was a surface inversion with a strong gradient that was not properly reproduced by the model. After 17 June (period III), there were several days with rain and the model performance varied as a result of these varying meteorological conditions. In general, MM5 could reproduce most of the parameters such as wind direction, precipitation and temperature reasonably well at the surface except low-wind speeds.

\subsubsection{Winter 2007}

January 2007 was warmer and had different meteorological conditions than January 2006 (Fig. 7). Temperatures were above zero except for a few days. During the first period (1-12 January), the wind speed was moderate to strong and some precipitation occurred. The second period (13-17 January) was dry and the wind speed was low. In the third period (18-25 January), the wind speed became higher and the temperature started decreasing. The wind speed was low again in the last period (26-31 January). The model-measurement agreement becomes worse under low-wind conditions (in the second and fourth period) as seen in the case of the previous year.

\subsubsection{Modification of the wind fields}

Meteorological variables such as wind speed and planetary boundary layer height (PBL) are the crucial parameters for the vertical mixing and dispersion of pollutants and thus these have a strong effect on surface concentrations. The simulation of the wind fields over complex terrain is known to be challenging (Liu et al., 2007; Baertsch-Ritter et al., 2004). Inspite of using FDDA techniques to obtain more realistic meteorological data, the modelled wind speeds still show discrepancies compared to measurements, especially over regions where wind speeds are low both in winter and summer periods (see Figs. 2, 6, 7). Wind speed is crucial for the photochemical modelling as high speeds dilute air pollution plumes and reduce pollutant concentrations. The average measured wind speeds at 12 surface meteorological 

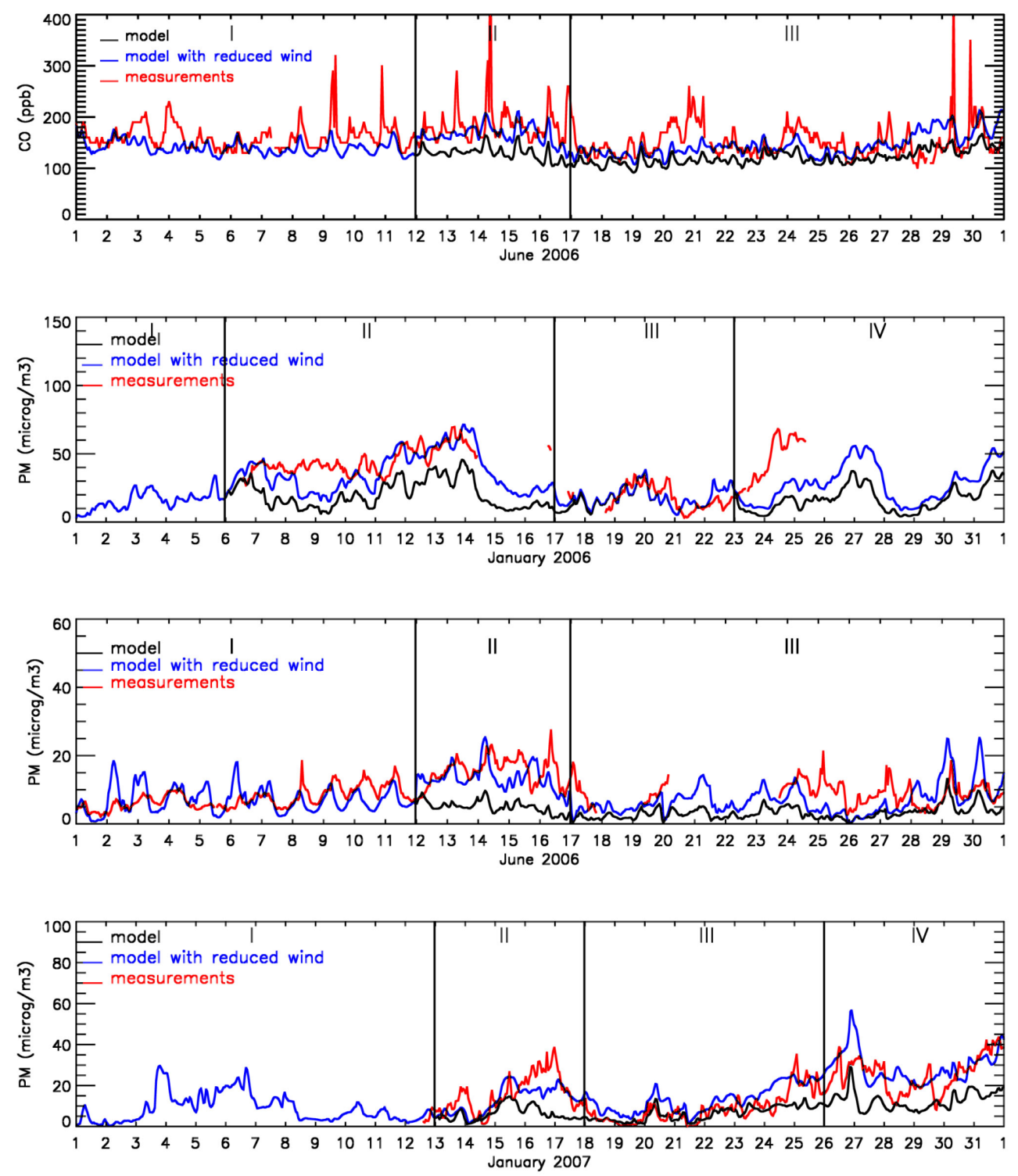

Fig. 9. Effect of reduced wind speed on CO in June 2006 (Payerne), and on PM in January 2006 (Zurich), June 2006 (Payerne), January 2007 (Payerne).

stations were $1.7 \mathrm{~m} \mathrm{~s}^{-1}, 1.8 \mathrm{~m} \mathrm{~s}^{-1}$, and $2.5 \mathrm{~m} \mathrm{~s}^{-1}$ for January 2006, June 2006 and January 2007, respectively whereas the simulated wind speeds in the lowest layer of the smallest domain were $2.8 \mathrm{~m} \mathrm{~s}^{-1}, 2.9 \mathrm{~m} \mathrm{~s}^{-1}$, and $3.5 \mathrm{~m} \mathrm{~s}^{-1}$. In a sensitivity test, reducing the wind speed by a factor of two in all domains and layers improved the results of the low-wind speeds significantly. Therefore, the reduced wind speeds were used in further simulations for the low-wind periods. The used procedure ensured mass conservation. We changed only the horizontal wind fields $(u, v)$ for each vertical level. Since only these fields are transferred to CAMx, which then calculates the vertical component $w$ at the layer interfaces internally, the mass conservation is fulfilled. The comparison of wind speeds before and after the modification is shown at some stations for each simulation period (Fig. 8).

An example for the effect of reduced wind speed on pollutant concentrations in each episode is shown in Fig. 9. Carbon monoxide $(\mathrm{CO})$ can be used as a proxy for the quality of the meteorology since its concentration does not change rapidly due to chemical reactions. The $\mathrm{CO}$ concentrations were underestimated during the low-wind periods where there were significant differences between model predictions and measurements of wind speed. Reducing the wind speed after 12 June improved the model performance for CO. The comparison of the modelled $\mathrm{PM}$ concentrations $\left(\mathrm{PM}_{2.5}\right)$ with the AMS measurements is also shown in Fig. 9. Modelled 

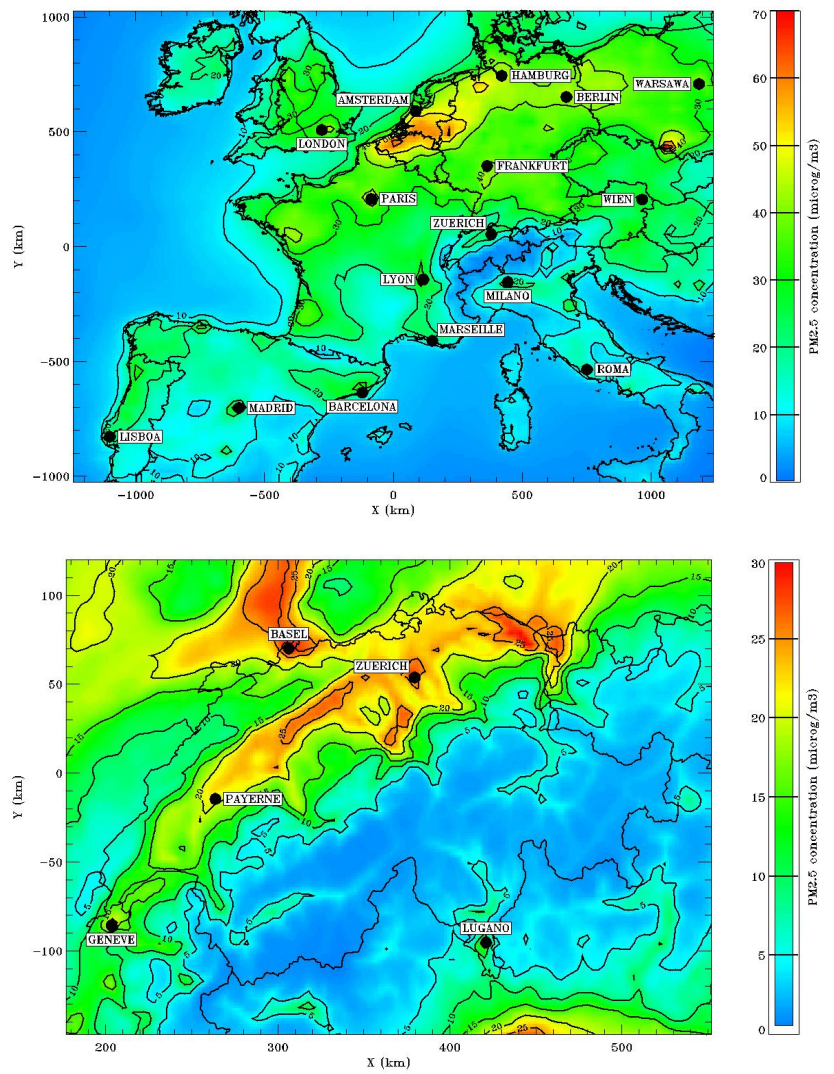

Fig. 10. Modelled monthly average $\mathrm{PM}_{2.5}$ concentration in January 2006 in the European $(27 \mathrm{~km} \times 27 \mathrm{~km})$ (top) and Swiss domains $(3 \mathrm{~km} \times 3 \mathrm{~km})$ (bottom).

PM concentrations increased by a factor of $2-3$ when wind speeds were reduced in low-wind periods and matched measurements much better. All the simulations with CAMx discussed in the following sections were performed with modified wind speeds.

\section{Results and discussion}

\subsection{Total aerosol}

The modelled $\mathrm{PM}_{2.5}$ refers to the sum of primary aerosol (EC and POA) and secondary inorganic (particulate nitrate, sulphate, ammonium) and organic aerosol (SOA). The predicted monthly average $\mathrm{PM}_{2.5}$ concentrations in the European and Swiss domains $(27 \mathrm{~km}$ and $3 \mathrm{~km}$ resolutions, respectively) are shown in Figs. 10-12 for all episodes. In January 2006, the modelled concentrations reach up to $70 \mu \mathrm{g} \mathrm{m}^{-3}$ around the Ruhr area (Germany) and Krakow (Poland) where there are substantial industrial emissions (Fig. 10). Primary aerosol dominates modelled $\mathrm{PM}_{2.5}$ at Krakow whereas aerosols are mainly secondary around the Ruhr area. Elevated levels can be seen around the large urban areas as well. Monthly average $\mathrm{PM}_{2.5}$ concentrations in the highresolution Swiss domain $(3 \mathrm{~km} \times 3 \mathrm{~km})$ are highest over the
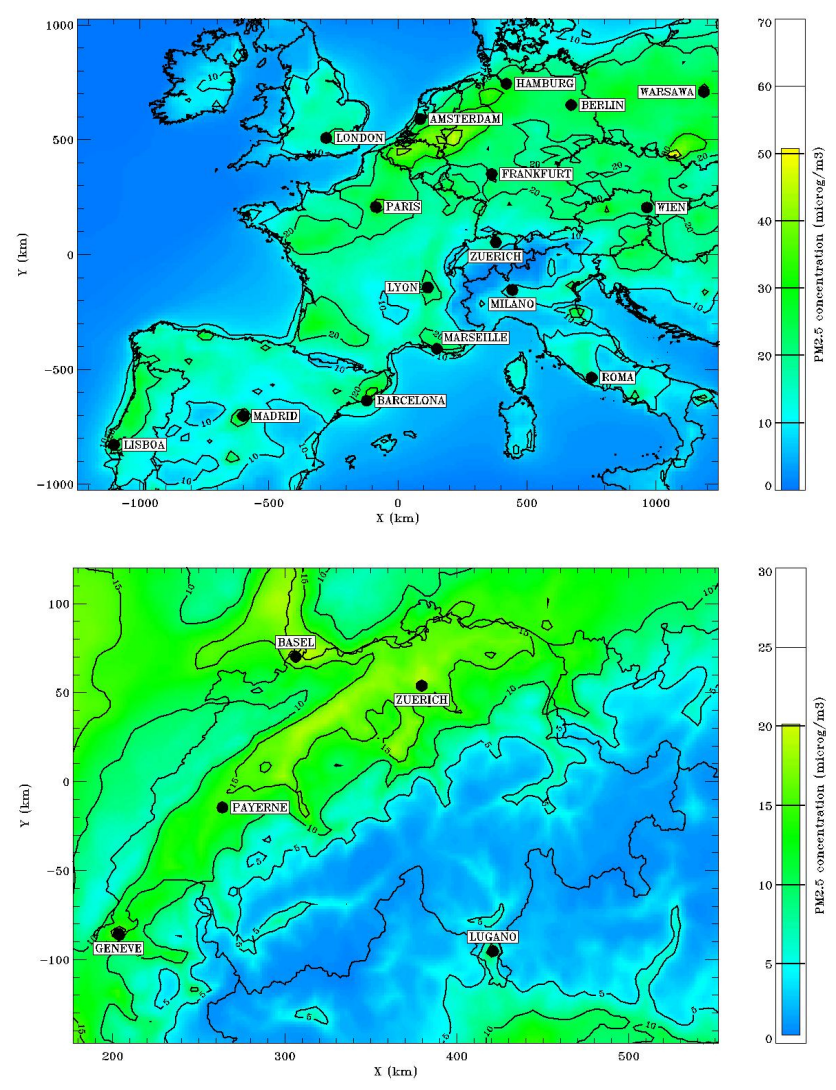

Fig. 11. Modelled monthly average $\mathrm{PM}_{2.5}$ concentration in January 2007 in the European $(27 \mathrm{~km} \times 27 \mathrm{~km})$ (top) and Swiss domains $(3 \mathrm{~km} \times 3 \mathrm{~km})$ (bottom).

Swiss Plateau (region between Jura mountains and Alps) and they exceed the national ambient air quality standards especially in areas downwind of Zurich (modelled daily averages are as high as $65 \mu \mathrm{g} \mathrm{m}^{-3}$ ) and Basel. The short-term standard for $\mathrm{PM}_{10}$ concentrations averaged over $24 \mathrm{~h}$ is $50 \mu \mathrm{g} \mathrm{m}{ }^{-3}$ in Switzerland. The long-term measurements suggest that the $\mathrm{PM}_{2.5} / \mathrm{PM}_{10}$ ratio is about 0.75 (Gehrig and Buchmann, 2003). High concentrations are also predicted in the southern part of the modelled domain.

The second winter episode in January 2007 was much warmer than January 2006. As seen in Fig. 11, the distribution of predicted $\mathrm{PM}_{2.5}$ particles in January 2007 is similar to the case in January 2006, however, concentrations are lower.

In summer, the distribution of $\mathrm{PM}_{2.5}$ particles in Europe is different from winter, as exemplified in Fig. 12. Although highest levels can still be seen around the Ruhr area (mainly particulate nitrate and primary aerosols) and Krakow (mainly primary aerosols and particulate sulphate), large urban areas are predicted to have much lower $\mathrm{PM}_{2.5}$ concentrations in summer than in winter. The model predicted that a significant contribution to $\mathrm{PM}_{2.5}$ in the European domain is due to SOA especially in the region from Berlin to the Adriatic sea (Fig. 13). 

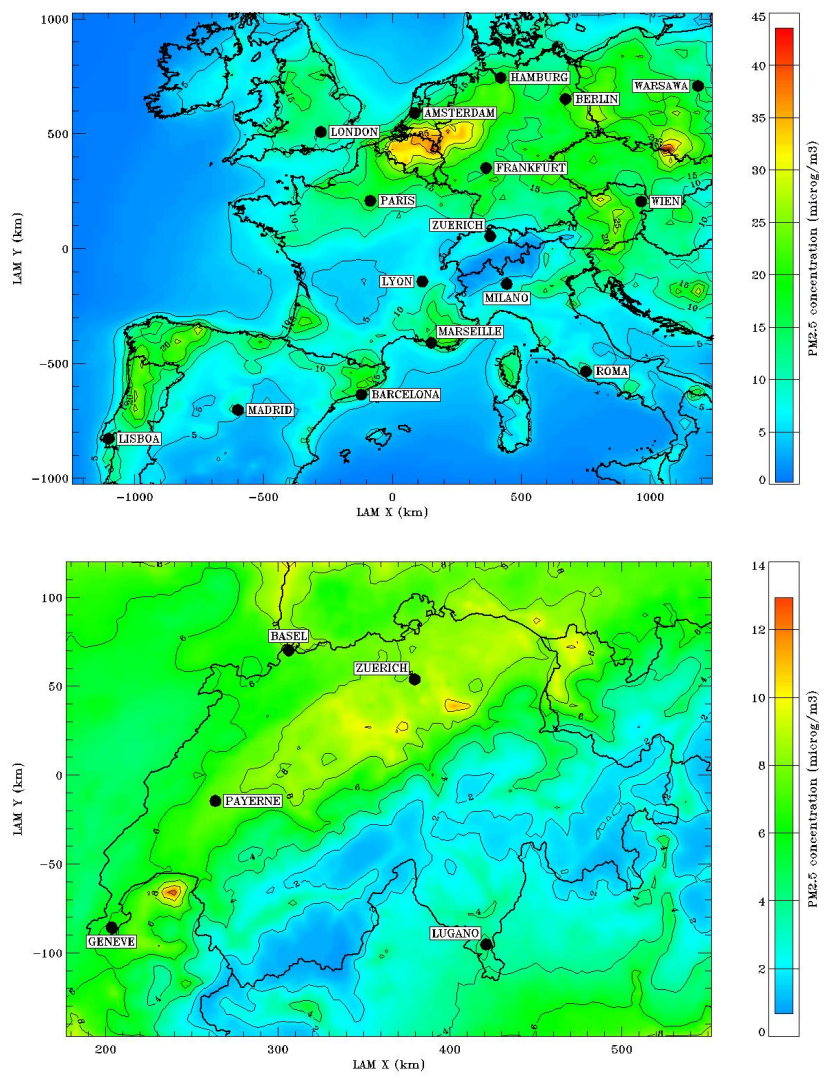

Fig. 12. Modelled monthly average $\mathrm{PM}_{2.5}$ concentration in June 2006 in the European $(27 \mathrm{~km} \times 27 \mathrm{~km})$ (top) and Swiss domains $(3 \mathrm{~km} \times 3 \mathrm{~km})$ (bottom).

There were detailed AMS $\left(\mathrm{PM}_{1}\right)$ measurements at Zurich in January 2006, and at Payerne in June 2006 as well as in January 2007. In addition, there were daily $\mathrm{PM}_{2.5}$ measurements at Payerne in June 2006 and January 2007. Moreover, hourly $\mathrm{PM}_{10}$ measurements were available in all three episodes. A comparison of model predictions for $\mathrm{PM}_{2.5}$ in the high-resolution domain $(3 \mathrm{~km} \times 3 \mathrm{~km})$ with the available measurements in all episodes is shown in Fig. 14. Clearly the particle concentrations were higher in January 2006 than in the other episodes. In January 2006, model results and measurements were similar during the high-wind periods (I and III), and the different measured size fractions yielded quite similar results. In the low-wind periods (II and IV), on the other hand, model results were lower than measurements on some days and there was a large difference between the measured $\mathrm{PM}_{10}$ and $\mathrm{PM}_{1}$ concentrations in the second period indicating increased coarse mode levels. The average concentration of modelled $\mathrm{PM}_{2.5}$ in January 2006 was $27.0 \mu \mathrm{g} \mathrm{m}$ which was close to the average measured $\mathrm{PM}_{1}$ concentration of $29.1 \mu \mathrm{g} \mathrm{m}^{-3}$. In June 2006, model results (average $\mathrm{PM}_{2.5}$ $8.1 \mu \mathrm{g} \mathrm{m}^{-3}$ ) matched both daily $\mathrm{PM}_{2.5}$ (average $9.9 \mu \mathrm{g} \mathrm{m}^{-3}$ ) and hourly $\mathrm{PM}_{1}$ (AMS, average $8.2 \mu \mathrm{g} \mathrm{m}^{-3}$ ) measurements (which were similar) rather well. The high $\mathrm{PM}_{10}$ concen-

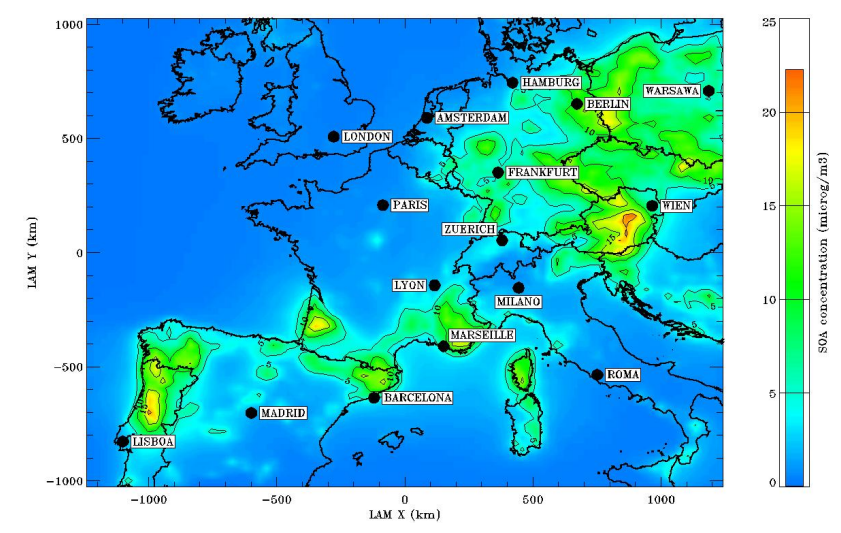

Fig. 13. Modelled monthly average secondary organic aerosol (SOA) concentration in June 2006 in the European domain $(27 \mathrm{~km}$ $\times 27 \mathrm{~km})$.

trations measured on 20-21 June 2006 correspond to a Saharan dust event observed at that time. In January 2007, PM levels were lower than those in the previous year, and the model (average $\mathrm{PM}_{2.5} 14.6 \mu \mathrm{g} \mathrm{m}^{-3}$ ) reproduced the measured $\mathrm{PM}_{2.5}$ concentrations (average $13.3 \mu \mathrm{g} \mathrm{m}^{-3}$ ) reasonably well.

Model predictions in the European domain were also compared with measurements. Figures S1-S3 shows the measured and modelled $\mathrm{PM}_{2.5}$ concentrations at Harwell (UK) for each of the studied episodes. In spite of the coarser resolution of the European domain $(27 \mathrm{~km} \times 27 \mathrm{~km})$ the model could reproduce $\mathrm{PM}_{2.5}$ levels reasonably well most of the time. The average values for model and measurements were 13.2 and $13.9 \mathrm{\mu g} \mathrm{m}^{-3}$ in January 2006, 12.3 and 13.5 in June 2006 , respectively. In January 2007, model results were similar to measurements during the first three weeks, however an overestimation occurred in the last week.

\subsection{Chemical composition}

The predicted chemical composition was compared with the AMS measurements. Although the model results consist of $\mathrm{PM}_{2.5}$ and the AMS measures particles smaller than $1 \mu \mathrm{m}$, they can be compared with each other since the difference between $\mathrm{PM}_{1}$ and $\mathrm{PM}_{2.5}$ measurements is usually rather small, as seen in Fig. 14. Both measurements and model results suggest that in winter particulate nitrate and organic aerosol are the main components of aerosols (Fig. 15). This is the case for both winter episodes in 2006 and 2007 at Zurich and Payerne, respectively. On the other hand, organic aerosol dominates the particle composition in summer. The model reproduces the relative contribution of aerosol species very well both in the winter and summer periods. The absolute concentrations from the AMS measurements are about $20 \%$ higher than model predictions in winter and summer 2006. In winter 2007, measured and modelled concentrations were similar except for modelled OA which was $17 \%$ lower than 
Table 3. Statistical parameters for aerosol components at Zurich (urban background) and Payerne (rural) in three episodes. CE is the collection efficiency (determined from sulfate filter measurements) used in AMS measurements. EC was measured by an aethalometer. The bold numbers indicate the time when the model performance criteria are met (MFE $\leq+75 \%$ and $-60<$ MFB $<+60 \%$ ) $*$.

\begin{tabular}{|c|c|c|c|c|c|c|c|c|c|c|c|c|c|c|c|}
\hline \multirow{2}{*}{$\begin{array}{l}\text { Aerosols } \\
\left(\mu \mathrm{g} \mathrm{m}^{-3}\right)\end{array}$} & \multicolumn{5}{|c|}{ January 2006 (Zurich) } & \multicolumn{5}{|c|}{ June 2006 (Payerne) } & \multicolumn{5}{|c|}{ January 2007 (Payerne) } \\
\hline & Model & $\begin{array}{r}\text { Obs. } \\
\mathrm{CE}=0.5\end{array}$ & RMSE & $\begin{array}{r}\text { MFB } \\
(\%)\end{array}$ & $\begin{array}{r}\text { MFE } \\
(\%)\end{array}$ & Model & $\begin{array}{r}\text { Obs. } \\
\text { CE }=1\end{array}$ & RMSE & $\begin{array}{r}\text { MFB } \\
(\%)\end{array}$ & $\begin{array}{r}\text { MFE } \\
(\%)\end{array}$ & Model & $\begin{array}{c}\text { Obs. } \\
\mathrm{CE}=1\end{array}$ & RMSE & $\begin{array}{r}\text { MFB } \\
(\%)\end{array}$ & $\begin{array}{r}\text { MFE } \\
(\%)\end{array}$ \\
\hline $\mathrm{NO}_{3}$ & 9.56 & 11.47 & 7.26 & $-\mathbf{1 7}$ & 55 & 0.97 & 0.99 & 1.53 & -91 & 140 & 6.89 & 5.66 & 3.0 & 36 & 58 \\
\hline $\mathrm{SO}_{4}$ & 3.11 & 6.06 & 4.76 & -65 & 98 & 1.36 & 1.56 & 1.10 & -28 & 63 & 1.82 & 1.43 & 1.87 & 3 & 74 \\
\hline $\mathrm{NH}_{4}$ & 3.90 & 5.58 & 3.37 & -38 & 60 & 0.79 & 1.07 & 0.83 & -49 & 77 & 2.67 & 2.07 & 1.27 & 36 & 58 \\
\hline $\mathrm{OA}$ & 9.83 & 13.45 & 5.70 & -28 & 39 & 4.51 & 6.00 & 3.10 & -35 & 50 & 5.31 & 6.37 & 4.10 & 2 & 59 \\
\hline $\mathrm{EC}$ & 3.50 & 2.17 & 2.22 & 43 & 56 & 0.69 & 0.95 & 0.46 & -19 & 36 & 1.13 & 1.02 & 0.50 & 20 & 41 \\
\hline
\end{tabular}

* Mean Fractional Bias, MFB $=\frac{1}{N} \sum_{t=1}^{N} \frac{C_{\text {mod }}(t)-C_{\text {obs }}(t)}{\left(C_{\mathrm{obs}}(t)+C_{\bmod }(t)\right) / 2} \times 100$ Mean Fractional Error, MFE $=\frac{1}{N} \sum_{t=1}^{N} \frac{\left|C_{\bmod }(t)-C_{\mathrm{obs}}(t)\right|}{\left(C_{\mathrm{obs}}(t)+C_{\bmod }(t)\right) / 2} \times 100$.

$N$ : number of effective data in the period without the spin-up day.

$C_{\text {mod }}(t)$ and $C_{\mathrm{obs}}(t)$ : simulated and observed concentrations at time $t$, respectively (USEPA, 1991; Boylan and Russell, 2006).
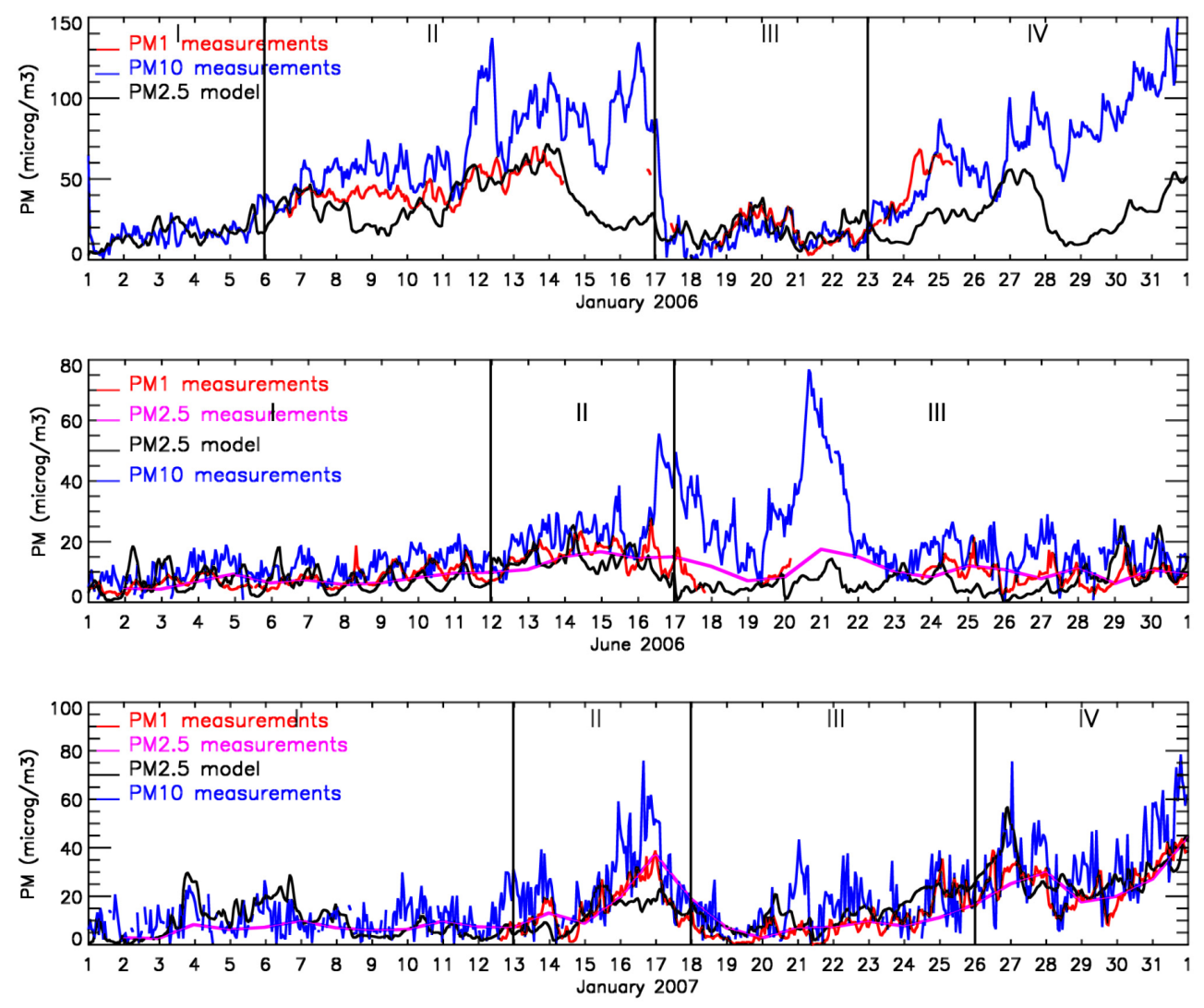

Fig. 14. Comparison of $\mathrm{PM}_{1}$ (hourly), $\mathrm{PM}_{2.5}$ (daily) and $\mathrm{PM}_{10}$ (hourly) measurements with $\mathrm{PM}_{2.5}$ (hourly) model predictions at Zurich in January 2006 (top), at Payerne in June 2006 (middle) and at Payerne in January 2007 (bottom). 

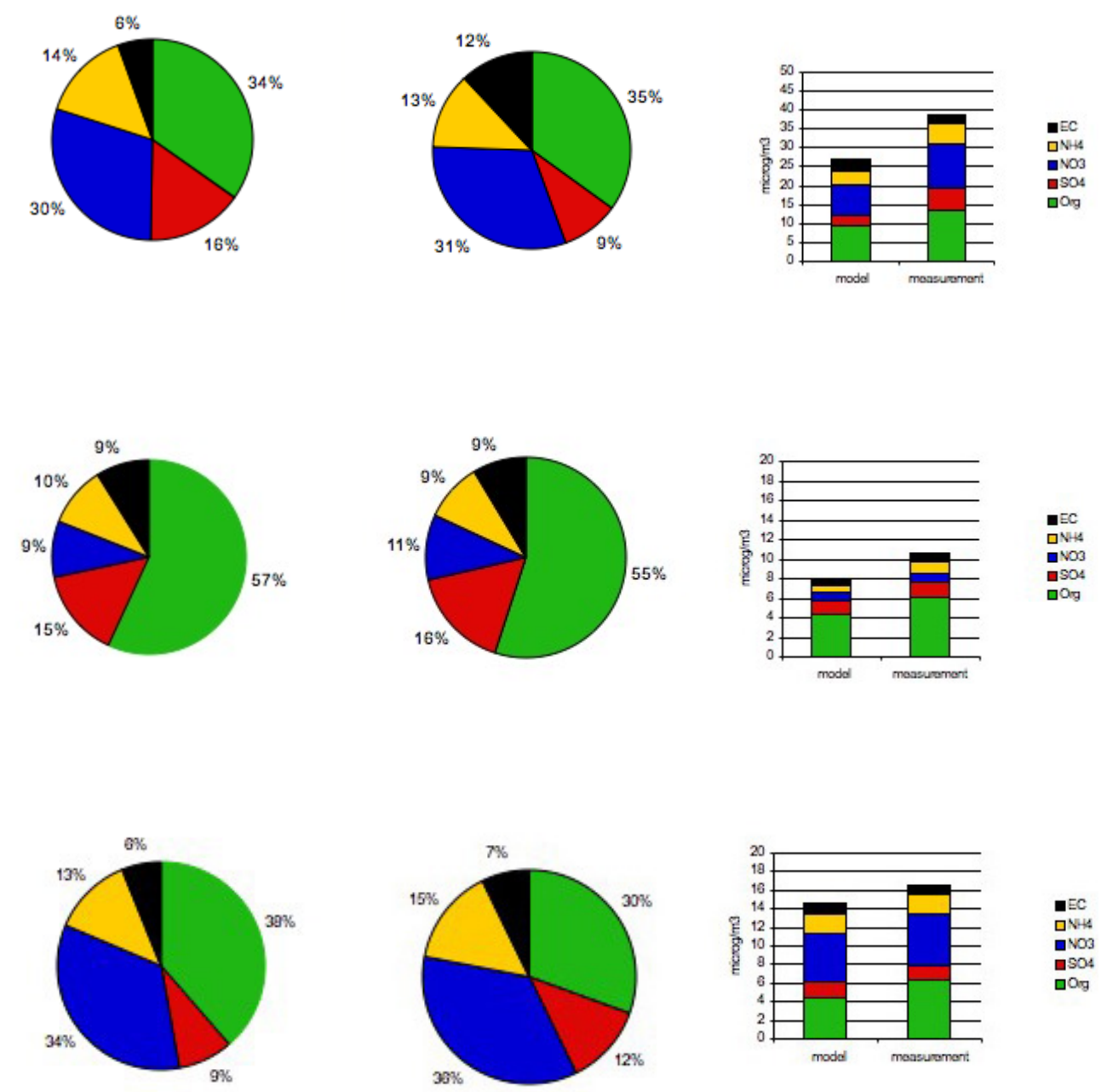

Fig. 15. Fractional composition of measured (left) and modelled (middle) aerosols as well as absolute concentrations (right) in January 2006 at Zurich (top), in June 2006 at Payerne (middle) and in January 2007 at Payerne (bottom).

Table 4. The POA and SOA fractions from model simulations and from AMS measurements using factor analysis.

\begin{tabular}{l|cc|cc}
\hline periods & \multicolumn{2}{|c|}{ measurements } & \multicolumn{2}{c}{ model } \\
& POA (\%) & SOA (\%) & POA (\%) & SOA (\%) \\
\hline January 2006 (Zurich) & 45 & 55 & 53 & 47 \\
June 2006 (Payerne) & 6 & 94 & 26 & 74 \\
January 2007 (Payerne) & 29 & 71 & 38 & 62 \\
\hline
\end{tabular}

the measurements. The model results were evaluated using the statistical parameters such as the mean fractional error (MFE) and the mean fractional bias (MFB) recommended by Boylan and Russell (2006) for aerosols. The statistical evaluation of model results is shown in Table 3 for all the episodes. The lowest Root Mean Square Error (RMSE) was obtained for EC in all episodes. The acceptable model per- formance criteria (MFE $\leq+75 \%$ and $-60 \%<\mathrm{MFB}<+$ $60 \%$ ) were met for all species only in January 2007. Performance criteria are met in January 2006 at Zurich for all species except sulfate. In June 2006, on the other hand, performance criteria are not met for nitrate and ammonium. The performance goals (when both MFE $\leq+50 \%$ and $-30 \%<$ MFB $<+30 \%$ are met) are obtained for OA in Zurich and for EC in Payerne in June.

The highest organic aerosol concentrations were measured in January 2006 during the low-wind period II at Zurich (Fig. 16). In general, the model could predict the low concentrations of organic aerosols reasonably well in the high-wind periods. In the winter low-wind periods (periods II and IV in January 2006 and 2007), however, the predicted OA is lower than the measured concentrations for several days. In winter 2006, about $53 \%$ of the modelled organic aerosols are predicted to be POA at Zurich. At Payerne, the fraction of POA is $38 \%$ and $26 \%$ in January 2007 and June 2006, respectively (Table 4). The modelled POA fractions are higher 

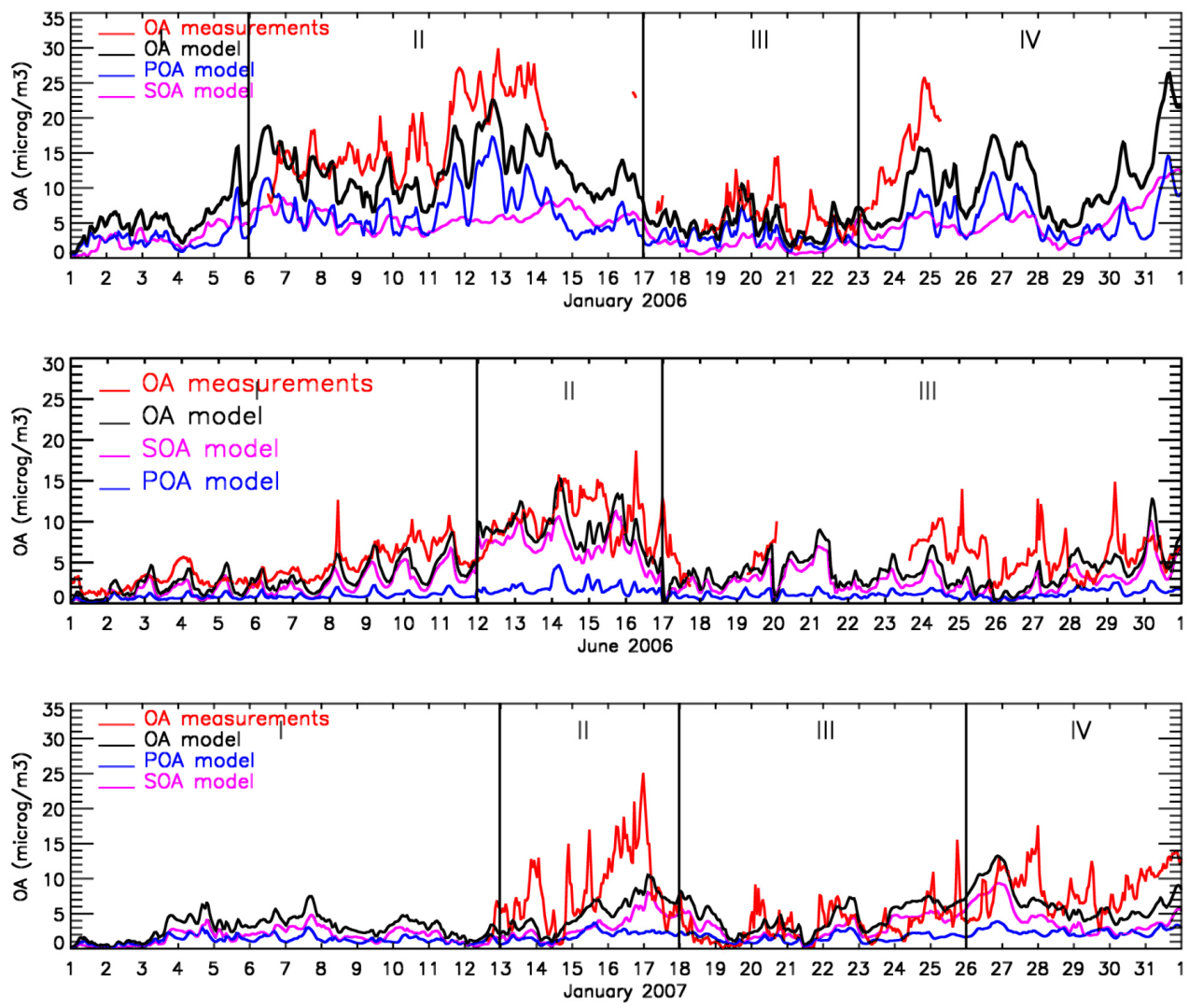

Fig. 16. Comparison of modelled and measured organic aerosols as well as modelled POA and SOA in January 2006 at Zurich (top), in June 2006 at Payerne (middle) and in January 2007 at Payerne.

than those derived from measurements using factor analysis of the aerosol mass spectral data (FA-AMS) (Lanz et al., 2008). Diurnal variations of POA and SOA predicted by the model and derived from measurements are shown in Fig. 17 for all periods. Both measured and modelled POA have two peaks in the winter periods; one in the morning and the other in the evening, where measured POA is taken as the sum of hydrocarbon-like organic aerosol (HOA) and wood burning organic aerosol (WBOA). Although morning peaks are similar, the evening peak from the measurements appears much later than that of the model indicating a more important contribution from wood burning that is underrepresented in the model. The measured POA and SOA show similar diurnal variations whereas the modelled SOA has no significant diurnal variation in winter. In summer, model and measurements show similar diurnal variations, with higher POA in the morning and higher SOA in the morning and at night. In general, the modelled SOA concentrations are lower than the measurements while POA is overestimated, especially in summer. The fact that POA is assumed to be non-volatile in CAMx can lead to too high POA and too low SOA, and better agreement can be found using the volatility basis set developed by Donahue et al. (2006) as shown for Mexico City (Hodzic et al., 2010). Similar diurnal cycles of mea- sured POA and SOA in winter support the hypothesis that some part of SOA might originate from the aging of POA.

The model results suggest that SOA originates mainly from biogenic VOCs in Switzerland. This is in agreement with studies using ${ }^{14} \mathrm{C}$ in Zurich showing that biogenic sources are dominant in summer (Szidat et al., 2006). The fractional compositions of modelled SOA for all the three episodes are shown in Fig. 18. In general, SOA in the model is formed basically from monoterpenes (blue), sesquiterpenes (green) and oligomerization of biogenic oxidation products (red). The contribution from anthropogenic precursors to SOA was predicted to be less than $1 \%$. In the winter periods, monoterpenes produce more SOA than sesquiterpenes, while the opposite is true in summer. In CAMx, sesquiterpene SOA is not allowed to partition back to the gas phase at higher temperatures due to its lower volatility, therefore it remains in the particulate phase. On the other hand, monoterpene SOA partitions to the gas phase at higher temperatures, which leads to a lower fraction in summer. One should keep in mind that the sesquiterpene emissions used in this study have a very high uncertainty. The assumption of sesquiterpene emissions as $10 \%$ of monoterpene emissions might be too high. With lower sesquiterpene emissions, the underestimation of OA would be significantly larger. The 

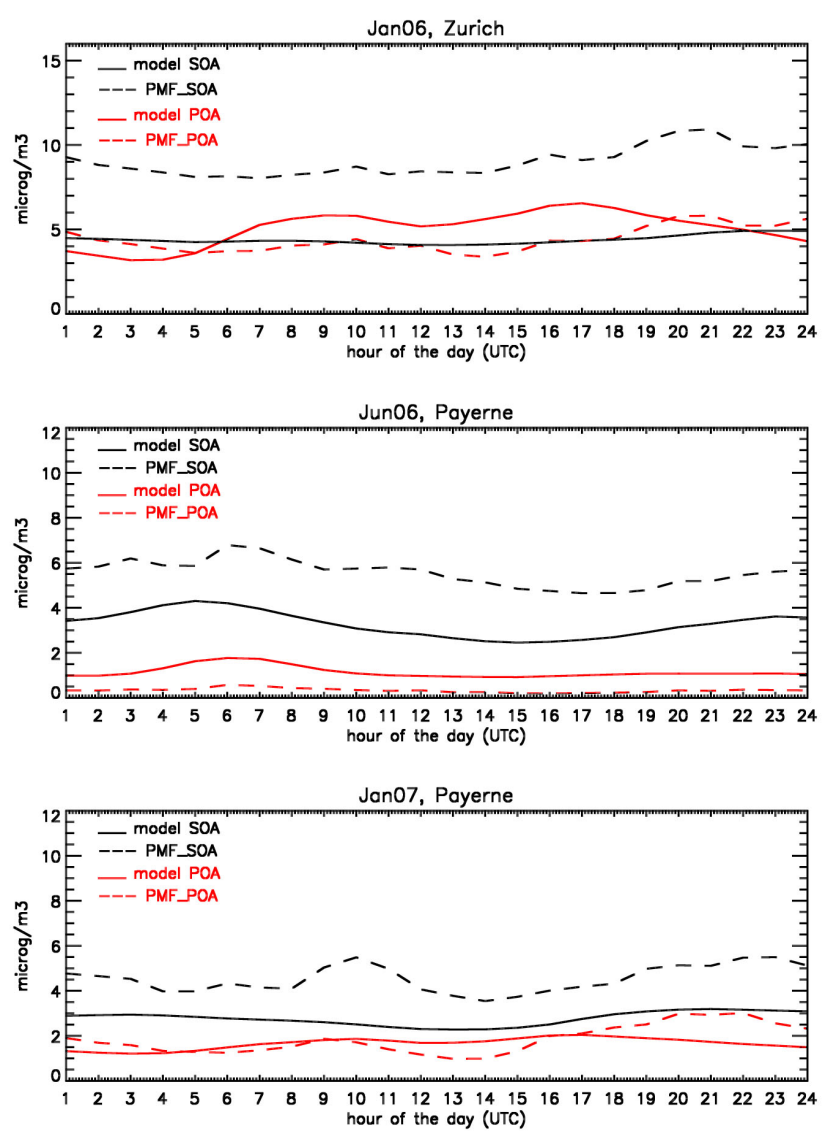

Fig. 17. Diurnal variation of monthly average measured (AMS, PMF) and modelled POA and SOA in January 2006 at Zurich (top), June 2006 at Payerne (middle) and January 2007 at Payerne (bottom).

emissions will be updated and a sensitivity study will be performed in the future.

\subsection{Sensitivity tests}

The deviation between measured and modelled temperature in the lowest model layer was about $\pm 5^{\circ} \mathrm{C}$ (see Fig. 2). The effect of this difference on aerosol concentrations is investigated by changing the temperature in the model by $5^{\circ} \mathrm{C}$. The variation in temperature affects mainly particulate nitrate concentrations. The results showed that particulate nitrate concentrations increased by up to $5 \mu \mathrm{g} \mathrm{m}^{-3}$ when the temperature was decreased by $5^{\circ} \mathrm{C}$ (Fig. 19a). An increase in the temperature by the same amount, on the other hand, caused a decrease of the nitrate levels by $2-3 \mu \mathrm{g} \mathrm{m}^{-3}$. SOA is also sensitive to temperature (Pun and Seigneur, 2008). However, changes in SOA concentrations due to temperature variations were very small (up to $0.2 \mu \mathrm{g} \mathrm{m}^{-3}$ ).
The effect of deposition processes on the aerosol concentrations was tested by switching off both dry and wet deposition in the simulations for January 2006. Dry deposition of oxidized gas-phase precursors of SOA is also included in CAMx. The total aerosol concentrations increased without deposition (Fig. 19b). Deposition mainly affects inorganic aerosol components, especially particulate nitrate due to efficient removal of nitric acid, and the degree of change depends on the meteorological conditions.

There are very few studies in Europe about the sensitivity of aerosols to precursor emissions, mainly in UK and northern Italy (Redington et al., 2009; Derwent et al., 2009; de Meij et al., 2009). In this study, the sensitivity of inorganic aerosol formation to $\mathrm{NO}_{\mathrm{x}}$ and $\mathrm{NH}_{3}$ emissions was investigated in whole Europe by two simulations for both January 2006 and June 2006, where either $\mathrm{NO}_{\mathrm{x}}$ or $\mathrm{NH}_{3}$ emissions were reduced by $50 \%$. Figure 20 shows the differences in monthly average $\mathrm{PM}_{2.5}$ concentrations between the two simulations for both winter and summer in both domains. The blue colour (negative values) shows regions where a $50 \%$ reduction in $\mathrm{NO}_{\mathrm{x}}$ results in a greater decrease of $\mathrm{PM}_{2.5}$ than a $50 \%$ reduction in $\mathrm{NH}_{3}$, while the red colour shows areas that are more sensitive to a reduction in $\mathrm{NH}_{3}$. These results suggest that aerosol formation in most of the European domain in winter (Fig. 20, top left) is more sensitive to $\mathrm{NH}_{3}$ emissions except in central Europe and north west of France where blue colour indicates a $\mathrm{NO}_{\mathrm{x}}$ sensitivity. Using a moving air-parcel trajectory model, Derwent et al. (2009) predicted that aerosol formation in southern UK was ammonia-limited. This is in line with our results for that region (Fig. 20, top left). As seen in Fig. 20 for the Swiss domain (bottom left), aerosol formation in the Swiss Plateau is limited by $\mathrm{NO}_{\mathrm{x}}$ emissions. On the other hand, the red colour in the southern part of the model domain (southern Switzerland, northern Italy) indicates a higher $\mathrm{NH}_{3}$ sensitivity for aerosol formation. These results support our earlier studies based on short-term simulations (Andreani-Aksoyoglu et al., 2008). In summer, effects of $\mathrm{NO}_{\mathrm{x}}$ and $\mathrm{NH}_{3}$ emission reductions on aerosol concentrations are predicted to be lower mostly due to lower ammonium nitrate concentrations (Fig. 20, right). In general, the sensitivity to $\mathrm{NH}_{3}$ emissions is weaker in summer due to higher $\mathrm{NH}_{3}$ emissions. The land area in Europe where aerosol formation is $\mathrm{NO}_{\mathrm{x}}$-limited in winter is about $3 \%$ whereas it goes up to $55 \%$ in summer. We also tested the sensitivity of aerosol formation to emission reductions lower than $50 \%$. The changes due to $15 \%$ emission reductions of either $\mathrm{NO}_{\mathrm{x}}$ or $\mathrm{NH}_{3}$ in January and June 2006 in the European domain are shown in Figs. S4-S5. The results are similar to those in Fig. 20 whereas absolute values are lower, as expected. 

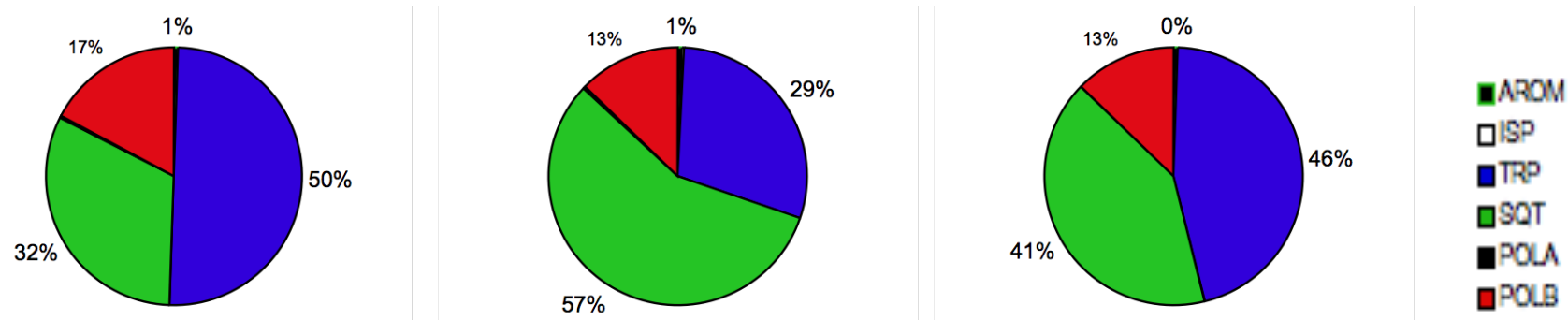

Fig. 18. Fractional composition of modelled SOA at Zurich in January 2006 (left), at Payerne in June 2006 (middle) and in January 2007 (right). AROM: aromatic precursors, ISP: isoprene, TRP: monoterpenes, SQT: sesquiterpenes, POLA: polymerized anthropogenic SOA, POLB: polymerized biogenic SOA.

a)

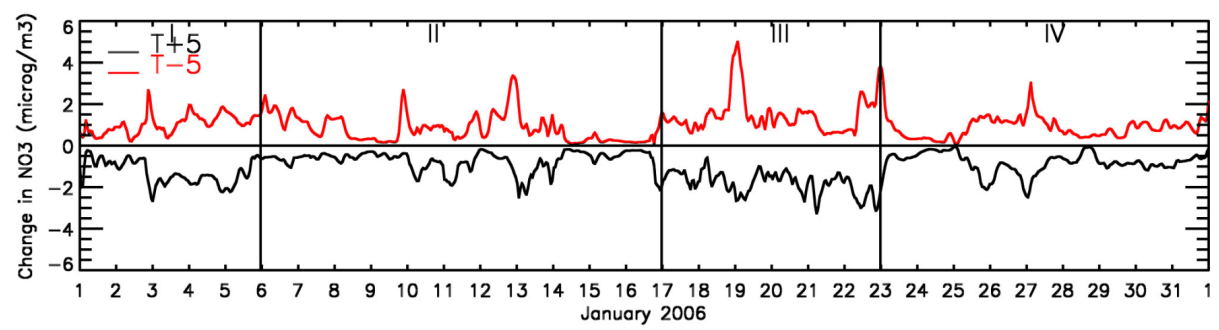

b)

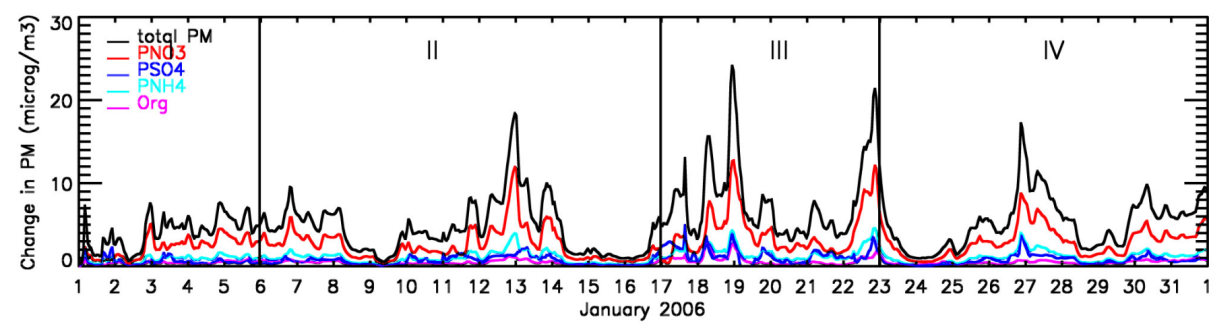

Fig. 19. Results of sensitivity tests, Zurich, January 2006. (a) Change in modelled nitrate concentrations when air temperature is modified (b) change in modelled $\mathrm{PM}_{2.5}$ concentrations when deposition processes are switched off.

\section{Conclusions}

The aerosols in Switzerland were modelled with the regional air quality model CAMx for one summer and two winter periods in 2006 and 2007 under different meteorological conditions. The following findings can be extracted from this study:

- Both measurements and model predictions suggest that organic particulate matter and particulate nitrate are the main aerosol components in winter. In summer, organic aerosol, which is mainly secondary, dominates the aerosol composition.

- The relative contribution of aerosol components was modelled very well. The absolute concentrations of aerosol components were in general reproduced rather well, except for the cold winter 2006 where the bias was higher than in the other periods. The acceptable model performance criteria were met for all investigated components in January 2007.

- In January 2006, the highest $\mathrm{PM}_{2.5}$ concentrations were predicted around the Ruhr area in Germany and Krakow in Poland; secondary inorganic aerosol and primary aerosol were calculated to be the main components in those areas, respectively. In summer, secondary aerosol dominated the aerosol composition both in Europe and in Switzerland.

- The contribution of the biogenic emissions to the SOA formation in Switzerland was predicted to be very large and to originate mainly from monoterpenes and sesquiterpenes, as well as oligomerization of biogenic oxidation products. 

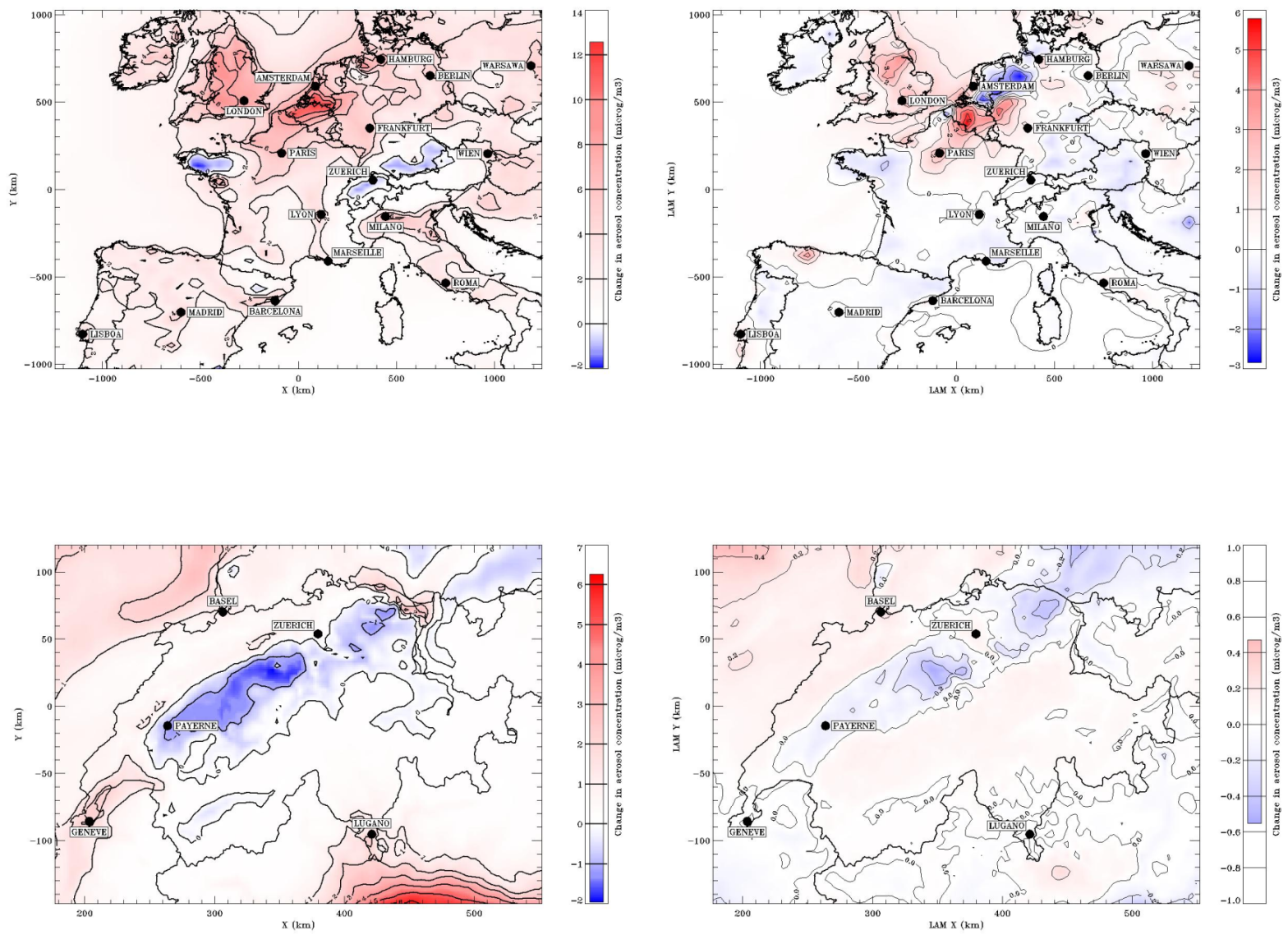

Fig. 20. Difference in monthly average aerosol concentration $\left(\mu \mathrm{g} \mathrm{m}^{-3}\right)$ between two simulations with a $50 \%$ emission reduction of either $\mathrm{NO}_{\mathrm{x}}$ or $\mathrm{NH}_{3}$ in January 2006 (left) and in June 2006 (right) for both European (top) and Swiss (bottom) domains. Aerosol formation is more sensitive to $\mathrm{NO}_{\mathrm{x}}$ emissions in blue regions and more sensitive to $\mathrm{NH}_{3}$ emissions in red regions.

- In all episodes, the predicted primary organic aerosol (POA) fraction was higher than those derived from the AMS measurements (especially in summer), probably because volatility of POA has not yet been taken into account in the CAMx model. Comparison of modelled and measured diurnal variations of POA and SOA indicates an important contribution from wood burning that is underrepresented in the model. The wood burning emissions will be updated in the near future.

- Sensitivity tests suggested that temperature and deposition have a strong effect mainly on particulate nitrate. Nitrate concentrations were inversely correlated with temperature. $\mathrm{PM}_{2.5}$ concentrations increased significantly (mainly inorganic aerosols) when the deposition processes were switched off.

- Simulations with reduced $\mathrm{NH}_{3}$ and $\mathrm{NO}_{\mathrm{x}}$ emissions indicated that inorganic aerosol formation is more sensitive to $\mathrm{NH}_{3}$ emissions in a large part of Europe (97\%) in winter. The effect of $\mathrm{NH}_{3}$ emission reductions on aerosol mass is predicted to be lower in summer $(45 \%)$.
On the other hand, model results suggest that aerosol formation over the Swiss Plateau is $\mathrm{NO}_{\mathrm{x}}$-limited in both seasons.

\section{Supplementary material related to this article is available online at: http://www.atmos-chem-phys.net/11/7355/2011/ acp-11-7355-2011-supplement.pdf.}

Acknowledgements. We thank MeteoSwiss, FUB, UBA, TNO, INFRAS, METEOTEST, EMPA, R. Alfarra and J. Sandradewi for providing various data. The post-processing software provided by $\mathrm{M}$. Tinguely is gratefully acknowledged. We also thank the European Centre for Medium-Range Weather Forecasts (ECMWF) for allowing the use of its Mozart data. This study was financially supported by the Swiss Federal Office of Environment (FOEN).

Edited by: R. Harley 


\section{References}

Andreani-Aksoyoglu, S. and Keller, J.: Estimates of monoterpene and isoprene emissions from the forests in Switzerland, J. Atmos. Chem., 20, 71-87, 1995.

Andreani-Aksoyoglu, S., Keller, J., Prévôt, A. S. H., Baltensperger, U., and Flemming, J.: Secondary aerosols in Switzerland and northern Italy: Modeling and sensitivity studies for summer 2003, J. Geophys. Res., 113, D06303, doi:06310.01029/02007JD009053, 2008.

Baertsch-Ritter, N., Keller, J., Dommen, J., and Prevot, A. S. H.: Effects of various meteorological conditions and spatial emissionresolutions on the ozone concentration and ROG/NO $\mathrm{x}$ limitationin the Milan area (I), Atmos. Chem. Phys., 4, 423-438, doi:10.5194/acp-4-423-2004, 2004.

BFS: GEOSTAT Benuetzerhandbuch, Bern, available at: http://www.bfs.admin.ch/bfs/portal/de/index/dienstleistungen/ geostat.htm, 1999.

Boylan, J. W. and Russell, A. G.: PM and light extinction model performance metrics, goals, and criteria for three-dimensional air quality models, Atmos. Environ., 40, 4946-4959, 2006.

Builtjes, P., van Loon, M., Schaap, M., Teeuwisse, S., Visschedijk, A. J. H., and Bloos, J. P.: The development of an emission data base over Europe and further contributions of TNO-MEP, Freie Universitaet Berlin/Institut fuer Meteorologie und Troposphaerischer Umweltforschung, Berlin, 70, 2002.

Carlton, A. G., Turpin, B. J., Altieri, K. E., Seitzinger, S. P., Mathur, R., Roselle, S. J., and Weber, R. J.: CMAQ Model Performance Enhanced When In-Cloud Secondary Organic Aerosol is Included: Comparisons of Organic Carbon Predictions with Measurements, Environ. Sci. Technol., 42, 8798-8802, 2008.

Carlton, A. G., Pinder, R. W., Bhave, P. V., and Pouliot, G. A.: To What Extent Can Biogenic SOA be Controlled?, Environ. Sci. Technol., 44, 3376-3380, 2010.

Chang, J. S., Brost, R. A., Isaksen, I. S. A., Madronich, S., Middleton, P., Stockwell, W. R., and Walcek, C. J.: A three-dimensional eulerian acid deposition model : Physical concepts and formulation, J. Geophys. Res., 92, 14681-14700, 1987.

CITY -DELTA European Modelling Exercise. An Inter-comparison of long-term model responses to urban-scale emission-reduction scenarios, available at: http://aqm.jrc.it/citydelta/, 2002.

COSMO: Newsletter No. 2, Deutscher Wetterdienst, Offenbach (D), available at: http://www.cosmo-model.org/, 2002.

de Meij, A., Thunis, P., Bessagnet, B., and Cuvelier, C.: The sensitivity of the CHIMERE model to emissions reduction scenarios on air quality in Northern Italy, Atmos. Environ., 43, 1897-1907, 2009.

Derwent, R., Witham, C., Redington, A., Jenkin, M., Stedman, J., Yardley, R., and Hayman, G.: Particulate matter at a rural location in southern England during 2006: Model sensitivities to precursor emissions, Atmos. Environ., 43, 689-696, 2009.

Donahue, N. M., Robinson, A. L., Stanier, C. O., and Pandis, S. N.: Coupled Partitioning, Dilution, and Chemical Aging of Semivolatile Organics, Environ. Sci. Technol., 40, 2635-2643, 2006

Dzepina, K., Volkamer, R. M., Madronich, S., Tulet, P., Ulbrich, I. M., Zhang, Q., Cappa, C. D., Ziemann, P. J., and Jimenez, J. L.: Evaluation of recently-proposed secondary organic aerosol models for a case study in Mexico City, Atmos. Chem. Phys., 9, 5681-5709, doi:10.5194/acp-9-5681-2009, 2009.
Environ: User's Guide, Comprehensive Air Quality Model with Extensions (CAMx), Version 4.4, Environ International Corporation, California, 2008.

Gehrig, R., and Buchmann, B.: Characterising seasonal variations and spatial distribution of ambient $\mathrm{PM}_{10}$ and $\mathrm{PM}_{2.5}$ concentrations based on long-term Swiss monitoring data, Atmos. Environ., 37, 2571-2580, 2003.

Heldstab, J. and Wuethrich, P.: Emissionsmuster. Raeumliche Verteilung und Ganglinien fuer CO-/NMVOC-Emissionen, BAFU, Bern/Zürich, 15, 2006.

Hodzic, A., Jimenez, J. L., Madronich, S., Aiken, A. C., Bessagnet, B., Curci, G., Fast, J., Lamarque, J.-F., Onasch, T. B., Roux, G., Schauer, J. J., Stone, E. A., and Ulbrich, I. M.: Modeling organic aerosols during MILAGRO: importance of biogenic secondary organic aerosols, Atmos. Chem. Phys., 9, 6949-6981, doi:10.5194/acp-9-6949-2009, 2009.

Hodzic, A., Jimenez, J. L., Prévôt, A. S. H., Szidat, S., Fast, J. D., and Madronich, S.: Can 3-D models explain the observed fractions of fossil and non-fossil carbon in and near Mexico City?, Atmos. Chem. Phys., 10, 10997-11016, doi:10.5194/acp10-10997-2010, 2010.

Horowitz, L. W., Walters, S., Mauzerall, D. L., Emmons, L. K., Rasch, P. J., Granier, C., Tie, X., Lamarque, J.-F., Schultz, M. G., Tyndall, G. S., Orlando, J. J., and Brasseur, G. P.: A global simulation of tropospheric ozone and related tracers: Description and evaluation of MOZART, version 2., J. Geophys. Res., 108, 4784, doi:4710.1029/2002JD002853., 2003.

Hueglin, C., Buchmann, B., and Weber, R. O.: Long-term observation of real-world road traffic emission factors on a motorway in Switzerland, Atmos. Environ., 40, 3696-3709, 2006.

IPCC: Working Group 1 Report: The Physical Basis of Climate Change (Intergovernmental Panel on Climate Change, 2007), available at: http://www.ipcc.ch/publications_and_data/ar4/wg1/ en/contents.html, 2007.

Janjić, Z. I.: The Step-Mountain Eta Coordinate Model: Further Developments of the Convection, Viscous Sublayer, and Turbulence Closure Schemes, Mon. Weather Rev., 122, 927-945, 1994.

Jimenez, J. L., Canagaratna, M. R., Donahue, N. M., Prévôt, A. S H., Zhang, Q., Kroll, J. H., DeCarlo, P. F., Allan, J. D., Coe, H., Ng, N. L., Aiken, A. C., Docherty, K. S., Ulbrich, I. M., Grieshop, A. P., Robinson, A. L., Duplissy, J., Smith, J. D., Wilson, K. R., Lanz, V. A., Hueglin, C., Sun, Y. L., Tian, J., Laaksonen, A., Raatikainen, T., Rautiainen, J., Vaattovaara, P., Ehn, M., Kulmala, M., Tomlinson, J. M., Collins, D. R., Cubison, M. J., E, Dunlea, J., Huffman, J. A., Onasch, T. B., Alfarra, M. R., Williams, P. I., Bower, K., Kondo, Y., Schneider, J., Drewnick, F., Borrmann, S., Weimer, S., Demerjian, K., Salcedo, D., Cottrell, L., Griffin, R., Takami, A., Miyoshi, T., Hatakeyama, S., Shimono, A., Sun, J. Y., Zhang, Y. M., Dzepina, K., Kimmel, J. R., Sueper, D., Jayne, J. T., Herndon, S. C., Trimborn, A M., Williams, L. R., Wood, E. C., Middlebrook, A. M., Kolb, C. E., Baltensperger, U., and Worsnop, D. R.: Evolution of organic aerosols in the atmosphere, Science, 326, 1525-1529, doi:10.1126/science.1180353, 2009.

Kalberer, M., Paulsen, D., Sax, M., Steinbacher, M., Dommen, J., Prévôt, A. S. H., Fisseha, R., Weingartner, E., Frankevic, V., Zenobi, R., and Baltensperger, U.: Identification of polymers as major components of atmospheric organic aerosols, Science, $303,1659-1662,2004$ 
Keller, M. and de Haan, P.: Handbuch Emissionsfaktoren des Strassenverkehrs 2.1. Dokumentation, INFRAS/UBA Berlin/UBA Wien/BUWAL, Bern, 127, 2004.

Lanz, V. A., Alfarra, M. R., Baltensperger, U., Buchmann, B., Hueglin, C., and Prévôt, A. S. H.: Source apportionment of submicron organic aerosols at an urban site by factor analytical modelling of aerosol mass spectra, Atmos. Chem. Phys., 7, 1503-1522, doi:10.5194/acp-7-1503-2007, 2007.

Lanz, V. A., Alfarra, M. R., Baltensperger, U., Buchmann, B., Hueglin, C., Szidat, S., Wehrli, M. N., Wacker, L., Weimer, S., Caseiro, A., Puxbaum, H., and Prévôt, A. S. H.: Source attribution of submicron organic aerosols during wintertime inversions by advanced factor analysis of aerosol mass spectra, Environ. Sci. Technol., 42, 214-220, 2008.

Lanz, V. A., Prévôt, A. S. H., Alfarra, M. R., Weimer, S., Mohr, C., DeCarlo, P. F., Gianini, M. F. D., Hueglin, C., Schneider, J., Favez, O., D’Anna, B., George, C., and Baltensperger, U.: Characterization of aerosol chemical composition with aerosol mass spectrometry in Central Europe: an overview, Atmos. Chem. Phys., 10, 10453-10471, doi:10.5194/acp-10-10453-2010, 2010.

Liu, L., Andreani-Aksoyoglu, S., Keller, J., Braathen, G. O., Schultz, M., Prévôt, A. S. H., and Isaksen, I. S. A.: A photochemical modelling study of ozone and formaldehyde generation and budget in the Po basin, J. Geophys. Res., 112, D22303, doi:10.1029/2006JD008172, 2007.

Madronich, S.: The Tropospheric Visible Ultra-violet (TUV) model web page, National Center for Atmospheric Research, Boulder, CO, http://cprm.acd.ucar.edu/Models/TUV/, 2002.

Mahrer, F. and Vollenweider, C.: Landesforstinventar LFI, Eidgenössische Forschungsanstalt für Wald, Schnee und Landschaft (WSL), Birmensdorf, 1983.

Morris, R. E., Koo, B., Guenther, A., Yarwood, G., McNally, D., Tesche, T. W., Tonnesen, G., Boylan, J., and Brewer, P.: Model sensitivity evaluation for organic carbon using two multipollutant air quality models that simulate regional haze in the southeastern United States, Atmos. Environ., 40, 4960-4972, 2006.

NASA/GSFC, Total ozone mapping spectrometer, available at: http: //toms.gsfc.nasa.gov/ozone/ozone.html, 2005.

Nenes, A., Pandis, S. N., and Pilinis, C.: ISORROPIA: A new thermodynamic equilibrium model for multiphase multicomponent inorganic aerosols, Aquatic Geochemistry, 4, 123-152, 1998.

Passant, N. R.: Speciation of UK emissions of non-methane volatile organic compounds, AEA Technology, Culham, 289, 2002.

PSU/NCAR: MM5 Version 3 Tutorial Presentations, 2004.

Pun, B. K.: Development and initial application of the sesquiversion of MADRID, J. Geophys. Res., 113, D12212, doi:10.1029/2008JD009888, 2008.

Pun, B. K. and Seigneur, C.: Investigative modeling of new pathways for secondary organic aerosol formation, Atmos. Chem. Phys., 7, 2199-2216, doi:10.5194/acp-7-2199-2007, 2007.

Pun, B. K. and Seigneur, C.: Organic Aerosol Spatial/Temporal Patterns: Perspectives of Measurements and Model, Environ. Sci. Technol., 42, 7287-7293, 2008.
Redington, A. L., Derwent, R. G., Witham, C. S., and Manning, A. J.: Sensitivity of modelled sulphate and nitrate aerosol to cloud, $\mathrm{pH}$ and ammonia emissions, Atmos. Environ., 43, 3227-3234, 2009.

Robinson, A. L., Donahue, N. M., Shrivastava, M. K., Weitkamp, E. A., Sage, A. M., Grieshop, A. P., lane, T. E., Pierce, J. R., and Pandis, S. N.: Rethinking Organic Aerosols: Semivolatile emissions and photochemical aging Science, 315, 1259-1262, 2007.

Simpson, D., Winiwarter, W., Börjesson, G., Cinderby, S., Ferreiro, A., Guenther, A., Hewitt, N. C., Janson, R., Khalil, M. A. K., Owen, S., Pierce, T. E., Puxbaum, H., Shearer, M., Skiba, U., Steinbrecher, R., Tarrasón, L., and Öquist, M. G.: Inventorying emissions from nature in Europe, J. Geophys. Res., 104, 81138152, 1999.

Steinbrecher, R., Smiatek, G., Koeble, R., Seufert, G. N., Theloke, J., Hauff, K., Ciccioli, P., Vautard, R., and Curci, G.: Intra- and inter-annual variability of VOC emissions from natural and seminatural vegetation in Europe and neighbouring countries, Atmos. Environ., 43, 1380-1391, 2009.

Stern, R.: Erstellung einer europaweiten Emissionsdatenbasis mit Bezugsjahr 1995 und die Erarbeitung von Emissionsszenarien für die grossraeumige Ausbreitungsrechnungen mit REM/CALGRID, Freie Universitaet Berlin/Institut fuer Meteorologie und Troposphaerischer Umweltforschung, Berlin, 84, 2003.

Strader, R., Lurmann, F., and Pandis, S. N.: Evaluation of secondary organic aerosol formation in winter, Atmos. Environ., 33, 48494863, 1999.

Szidat, S., Jenk, T. M., Synal, H.-A., Kalberer, M., Wacker, L., Hajdas, I., Kasper-Giebl, A., and Baltensperger, U.: Contributions of fossil fuel, biomass burning, and biogenic emissions to carbonaceous aerosols in Zurich as traced by 14C, J. Geophys. Res., 111, D07206, doi:10.1029/2005JD006590, 2006.

Tsimpidi, A. P., Karydis, V. A., Zavala, M., Lei, W., Molina, L., Ulbrich, I. M., Jimenez, J. L., and Pandis, S. N.: Evaluation of the volatility basis-set approach for the simulation of organic aerosol formation in the Mexico City metropolitan area, Atmos. Chem. Phys., 10, 525-546, doi:10.5194/acp-10-525-2010, 2010.

USEPA: Guideline for regulatory application of the Urban Airshed Model, USEPA Report No. EPA-450/4-91-013., 1991.

Wesely, M. L.: Parameterization of surface resistances to gaseous dry deposition in regional-scale numerical models, Atmos. Environ., 23, 1293-1304, 1989.

Yarwood, G., Morris, R. E., Yocke, M. A., and Whitten, G. Z.: Updates to the Carbon Bond chemical mechanism: CB05. Final Report prepared for US EPA, 2005.

Zhang, Y., Huang, J.-P., Henze, D. K., and Seinfeld, J. H.: Role of isoprene in secondary organic aerosol formation on a regional scale, J. Geophys. Res., 112, D20207, doi:10.1029/2007JD008675, 2007. 